\title{
Securitization and Credit Risk: Evidence from Retained Interest in Securitized Mortgages
}

\author{
M. Scholz*
}

September 2013

\begin{abstract}
This paper analyzes bank- and loan-specific characteristics that determine the amount of retained interest held by US banks in mortgage securitizations. Economic theory suggests that retaining an interest in securitization transactions should help to mitigate information asymmetry problems between the parties involved. For a sample of bank holding companies, I find that credit risk of the transferred mortgages is positively associated with the amount of retained interest held, consistent with investor demand for a signal of (credit) quality of the securitized assets. The demand for such a signal seems to be lower for banks with an established reputation for securitization transactions. Consistent with the view of securitization as a sophisticated tool to manage risk from loan origination, more sophisticated banks seem to hold more retained interest. It also appears that retained interest is negatively associated with credit risk exposure from other assets. These findings suggest that retained interest in securitization transactions serves as a mechanism to mitigate information asymmetry problems as well as a means to manage a bank's risk profile.
\end{abstract}

Keywords: Retained Interest, Securitization, Mortgages, Credit Risk, Credit Risk Retention, MBS

JEL Classification: G21, G28, M40

*Dipl.-Kfm. Michael Scholz, Chair of Accounting and Auditing, Prof. Dr. Günther Gebhardt, Goethe University Frankfurt. Corresponding E-Mail: mscholz@wiwi.uni-frankfurt.de. I thank Moritz Bassemir, Günther Gebhardt, Christian Leuz, Edgar Löw, Zoltán Novotny-Farkas, Ken Peasnell, Michael Reiland, Patricia Ruffing, Anne Wyatt and participants at the 2012 CEQURA Junior Research Workshop in Munich, the 2013 IAAER/AS-VHB Conference in Eschborn, the 2013 EAA Congress in Paris, the 2013 International Workshop on Accounting and Regulation in Siena and members of the Department of Accounting \& Finance at Lancaster University for helpful comments. 


\section{Introduction}

Securitization has been at the heart of the financial crisis. In a securitization transaction a firm pools assets and issues securities with a right to payments backed by the pool of assets. ${ }^{1}$ US banks used this instrument on a large scale. The issuance volume of total asset-backed securities reached nearly $\$ 3$ trillion at its peak in 2005. A large part consisted of so called non-agency or private-label mortgage-backed securities with an issuance volume of almost $\$ 900$ billion. $^{2}$ When markets for securitization products dried up, severe mispricing of risks and conflicts of interest between parties involved in securitization transactions became evident (Fender and Mitchell, 2009a; Keys et al., 2010). The source of these problems were information asymmetries between securitizers and investors (Ashcraft and Schuermann, 2008). In response to those deficiencies of the securitization market, US Congress passed the Dodd-Frank Act in 2010, which requires that securitizers shall retain an economic interest in the credit risk of any asset-backed security. ${ }^{3}$ Basically, the required threshold is at least five percent with certain exemptions. US bank regulators are currently working on a final rule to implement this "skin in the game" requirement. ${ }^{4}$ Similarly, Article $122 \mathrm{a}$ of the Capital Requirement Directive II (2009) allows European banks only to invest in asset-backed securities if the securitizer retains a material economic interest of at least five percent.

Economic theory suggests that retaining an interest in securitization transactions should help to mitigate information asymmetry problems between the parties involved (Pennacchi, 1988; Boot and Thakor, 1993). So investors should demand securitizers to retain an interest in asset-backed securities even without any regulation. However, the severe problems of securitization transactions during the financial crisis raise concerns whether retained interest effectively worked as a mechanism to mitigate information asymmetry problems. These concerns and the regulatory intervention lead to two important empirical questions: First, did securitizers retain an interest in securitization transactions in the time before the Dodd-Frank Act and, in particular, in the period before the financial crisis? Second, what determines the amount of

$1 \quad$ See Greenbaum and Thakor (1987).

2 See SIFMA (2012a) and SIFMA (2012b). A non-agency or private-label security is any security that is not issued by a government agency, e.g., the Government National Mortgage Association (Ginnie Mae), or by a government-sponsored enterprise (GSE), e.g., the Federal Home Loan Mortgage Corporation (Freddie Mac) and the Federal National Mortgage Association (Fannie Mae).

3 See Section 941 of the Dodd-Frank Act (2010).

4 See Board of Governors of the Federal Reserve System (2013). For the discussion about the implementation of the final rule see also Board of Governors of the Federal Reserve System (2010); Senate Report 111-176 (2010); Federal Agencies (2011). 
retained interest when there is no regulation? Evidence on these questions is rather limited. In particular, there are hardly any empirical studies on the determinants of retained interest and there is none which focuses on the US setting.

This paper contributes to the research on securitization transactions by analyzing the amount of retained interest that US banks held from mortgage securitizations in the period before the financial crisis. It is the first study to provide empirical evidence on the determinants of retained interest in the US setting. The findings suggest that a large fraction of banks at least did not hold retained interest during the entire life of their mortgage-backed securities. Splitting sample banks into different groups according to their business models shows that banks with an originate-to-distribute business model held relatively small retained interest while having securitized assets with relatively high credit risk. This observation is consistent with the view that for this particular group of banks investors neglected the risk of the securitized mortgages. A possible explanation is that these banks were very active in the securitization market and that investors relied on the banks' established reputation for securitization transactions.

However, for the entire sample the analysis of the determinants of retained interest points towards a significantly positive association between credit risk of the securitized mortgages and the amount of retained interest. This result is consistent with investor demand for a signal of the (credit) quality of the securitized mortgages. In addition, banks that belong to the top issuers of mortgage-backed securities during the sample period hold less retained interest. The demand for a signal of the quality of the securitized assets therefore seems to be lower for banks with an established reputation for securitization transactions. I also find that more sophisticated banks seem to hold more retained interest. This observation is in line with the view of securitization as a sophisticated tool to manage risk from loan origination. Finally, retained interest appears to be negatively associated with credit risk exposure from other assets. Taken together, the findings suggest that retained interest in securitization transactions generally serves as a mechanism to mitigate information asymmetry problems as well as a means to manage a bank's risk profile.

The data used for the empirical analysis in this paper are obtained from FR Y-9C reports. Bank holding companies have to file these statements when they have total consolidated assets of $\$ 500$ million or more. Banks file these reports quarterly on a consolidated basis with the Federal Reserve. Since 2001 the reports require detailed information about banks' securitization activities, including information about retained interest and delinquencies of securitized loans. The empirical analysis uses a sample of 1,355 firm-quarters from 164 bank holding companies to examine 
the determinants of retained interest in the period from 2001 to 2006.

Most extant research has only indirectly documented risk retention in securitization transactions. Prior studies have focused on the impact of securitization transactions on securitizers' equity or credit risk. Niu and Richardson (2006) show that off-balancesheet debt of securitization structures has the same risk-relevance for explaining the securitizer's beta factor as on-balance-sheet debt. Landsman et al. (2008) examine the value relevance of securitized assets. Their findings suggest that market participants view securitized assets as belonging to the securitizing firm which is contrary to an effective risk transfer in securitization transactions. In other studies, there is evidence that the source of such risk retention is retained interest in the securitized assets. Chen et al. (2008) find that securitizers' stock return volatility is positively associated with retained interest. Barth et al. (2012) analyze the credit risk relevance of securitization transactions. They observe that credit risk is positively related to retained interest and not to the total volume of securitized assets when credit risk is measured using credit ratings.

There is little empirical research on the motives and the extent of risk retention in securitization transactions. The study that is most closely related to mine is Franke et al. (2012). The authors find that the amount of retained interest is negatively associated with the quality of the securitized assets in a sample of European CDO transactions. However, securitizations of US mortgages played a central role in the financial crisis. As Franke et al. (2012) note, in securitizations of mortgages there may be different measures for the quality of the securitized assets and the diversification of the mortgage pools is different from the pool of corporate loans and bonds in a European CDO transaction. It is therefore unclear whether the results for European CDO transactions hold for securitizations of US mortgages. My study aims to contribute to this question. It is the first study to analyze the relation between the credit risk of securitized mortgages and the amount of retained interest. Moreover, it is also the first study that identifies additional determinants of a securitizer's decision to retain interest such as the securitizer's reputation and sophistication.

The remainder of the paper is organized as follows. Section 2 describes the structure of a typical securitization transaction and reviews related literature. Section 3 develops the hypotheses about the determinants of retained interest. Section 4 discusses the sample selection procedure and the research design. Section 5 presents results from the empirical analysis and Section 6 concludes. 


\section{Background on Securitization Transactions}

\subsection{Typical Structure and Accounting Treatment}

Securitization is the process of transforming assets into securities, which are then called "asset-backed securities" (Kothari, 2006). In the following example of a bank securitizing a loan portfolio, I discuss the typical structure of a securitization transaction. Figure 1 depicts the simplified structure of the process.

\section{[Insert figure 1 here]}

The bank in this transaction is called the originator or transferor. It transfers a portfolio of loans (Loan Portfolio B in the example of Figure 1) to another entity. The entity which acquires the assets is referred to as the transferee. Often, the transferee is a special purpose entity (SPE) which is created by the bank for the sole purpose of acquiring the assets. The SPE then issues asset-backed securities which represent a claim on the future cash flows from the transferred assets. The cash proceeds from the issuance of the asset-backed securities are passed on to the originator as purchase price for the transferred assets. Typically, asset-backed securities are structured into different tranches with different risk profiles. In the example of Figure 1 the SPE issues four different tranches (tranche A to D). The tranches are tailored to meet the particular risk appetite of the investors in the asset-backed securities (Boot and Thakor, 1993; BCBS, 2011). One of the key differences of the tranches is the priority of claims, i.e. the specific order in which investors receive payments on the securities. Tranche A is structured as the senior class. Investors in tranche A are the first to receive payments on their securities. The claims of investors in the other tranches are subordinated. In the example of Figure 1 the other tranches are referred to as the mezzanine class, the junior class and the first-loss piece to indicate the descending order of the claims. If the cash flows generated by the transferred assets are not sufficient to settle all claims, investors in subordinated tranches will suffer losses. Thus, each tranche bears a different risk of loss. The most junior class is tranche D; this class is referred to as the first-loss piece. As this tranche is riskier than the others, investors usually do not purchase it. Instead, the originating bank takes the first-loss piece. In this way, the bank retains an interest in the transferred loans. That is why the tranche held by the bank is called retained interest. Retained interest can have different forms and is not restricted to the first-loss piece. Actually, if investors do not purchase the other tranches entirely, the bank will also take a part of the other tranches. 
Retained interest is a form of credit enhancement provided by the originating bank (Kothari, 2006). Credit enhancement is necessary to mitigate information asymmetry problems arising in the transfer of the assets (Pennacchi, 1988; Boot and Thakor, 1993; DeMarzo and Duffie, 1999; Chen et al., 2008; Landsman et al., 2008). The size of the credit enhancement is directly related to the cost of the transaction. ${ }^{5}$ Generally speaking, if the transferred assets are riskier the originator will have to provide more credit enhancement, e.g., in the form of a larger first-loss piece or retaining a part of the other subordinated tranches. In this way, the cost of the transaction increases because a smaller part of the tranches is sold to investors.

\subsection{Related Literature}

The role of securitization in the finanical crisis has triggered a large literature on securitization transactions. Among the primary issues investigated are the determinants of the decision to securitize assets, the effects on the originator's risk profile and the design of securitization transactions. ${ }^{6}$ More recently, there is also a debate on proposals to require securitizers to retain interest from securitizations. These proposals are the response to conflicts of interests which during the crisis became particularly evident between financial institutions and other stakeholders in the securitization chain (BCBS, 2011). As securitization transactions are most common with financial institutions (Dechow et al., 2010) most of the research concentrates on the financial industry and on securitization of loans.

With regard to the question why banks securitize, early theoretical papers conclude that in the 1980's the erosion of subsidies linked to deposit insurance, loan loss provisioning and housing seems to have prompted the growth of securitization as a substitute for traditional deposit financing (Cumming, 1987; Greenbaum and Thakor, 1987). Empirical findings from research on the determinants of loan sales by Pavel and Phillis (1987) support this view. However, their results also point to other important factors such as the need of banks to raise funds for using their competitive advantage in originating and servicing loans or the wish for asset diversification. More recent studies which specifically investigate securitization transactions conclude that regulatory arbitrage and bank size drive securitizations (Uzun and Webb, 2007). For the Spanish setting (Martín-Oliver and Saurina, 2007) and the Italian setting (Mazzuca and Agostino, 2009; Affinito and Tagliaferri, 2010) there is evidence that

$5 \quad$ For a detailed discussion of the different forms and the sizing of credit enhancements, see Kothari (2006), pp. 191-230.

6 See Schipper and Yohn (2007) for a survey of research related in particular to the accounting for securitization transactions. 
liquidity needs are an important determinant of the decision to securitize. Bannier and Hänsel (2008) analyze a comprehensive sample of European banks. They observe that a bank is more likely to securitize the higher its credit risk exposure, the lower its liquidity and the lower its performance. For a worldwide sample, Panetta and Pozzolo (2010) report similar results.

Studies on the effects of securitization on the originators risk profile generally suggest that capital market participants view risk transfer as limited. Niu and Richardson (2006) document that the off-balance-sheet debt backed by securitized assets has the same relevance for explaining firm beta as on-balance-sheet debt. Landsman et al. (2008) examine the value relevance of outstanding securitized assets and find that in the view of market participants the risk and rewards of the ownership of the transferred assets reside with the originator. They argue that an effective risk transfer cannot take place because the securitization structure must be bankruptcy remote. ${ }^{7}$ The originator achieves such bankruptcy remoteness through providing credit enhancements to the securitization structure. Primary credit enhancements are implicit recourse and retained interest. Implicit recourse is an informal understanding between the originator and the investors that the originator will not let the securitization structure fail. Retained interest serves as a costly signal concerning the quality of the transferred assets. Both means of risk retention impede an effective transfer of the risks of the securitized assets. Consistently, Casu et al. (2011) observe that banks with a greater balance of outstanding securitized assets choose on-balance-sheet portfolios of lower credit risk. However, this stream of research has not explicitly examined the effects of retained interest.

Another strand of literature has studied the effects of retained interest on the originators risk profile more closely. Barth et al. (2012) find that credit risk is positively associated with retained interest, but not with the amount of outstanding securitized assets, when the authors measure credit risk using credit ratings. When credit risk is measured using credit spreads, only the amount of outstanding securitized assets is risk relevant. Chen et al. (2008) study the relevance of outstanding securitized assets and retained interest for banks' equity risk. They find that the amount of outstanding securitized assets and some forms of retained interest are positively associated with banks' stock return volatility. They also show that on average the amount and type of retained interest depend on the class of the securitized assets, i.e. mortgages, consumer, or commercial and other loans. They explain this results by different characteristics across different asset classes. However, they do not analyze variation

$7 \quad$ An entity is a bankruptcy remote entity if chances of bankruptcy have been made remote. See Kothari (2006), p. 41. 
of factors like credit risk within asset classes.

Research on the structure of securitization transactions has dealt with the effect of variation in credit risk on the amount of retained interest. However, empirical research on this subject is still limited. Franke and Krahnen (2007) use a simulation model to analyze the risk sharing in collateralized debt obligation transactions and empirically test their findings on a dataset of 43 European collateralized loan obligation transactions. They show that the amount of retained interest increases with their measure of the expected credit risk of the securitized assets. Franke et al. (2012) extend this analysis to a sample of 169 European collateralized debt transactions of European corporate loans and bonds. Using information about the credit risk of these loans and bonds published by Moody's, the authors find that the amount of retained interest is strongly inversely related to asset pool quality as measured by credit risk. However, they limit the generality of their findings since their sample size is only modest and their dataset includes only collateralized debt obligations. They warn to apply their findings to securitizations of other claims like mortgages, because the measures for the quality of mortgages and the diversification of the mortgage pools are different from corporate loans and bonds. Instead, Franke et al. (2012) call for additional research on the US setting.

My paper follows the research by Franke et al. (2012). It is the first paper to examine the effect of credit risk of securitized mortgages on the amount of retained interest. One major contribution is the specific analysis of variation of credit risk within a single asset class. To identify additional determinants of a securitizer's decision to retain interest, the analysis also takes into account specific characteristics of the securitizing banks such as reputation and sophistication.

Another contribution of my paper is to inform the debate on proposals to require securitizers to retain interest in securitizations. The proposals for risk retention aim at aligning the interests of securitizers with the interests of investors in asset-backed securities. ${ }^{8}$ While some authors argue that retention regulation could in fact be detrimental, because the cost of retention reduces the margin for securitization of high-quality assets (Hattori and Ohashi, 2011), most authors and policy makers view retention as beneficial (see e.g. Malekan and Dionne, 2012). The proposals were turned into legislation with the Dodd-Frank Act (2010) in the US and the Capital Requirement Directive II (2009) in the EU. Currently, the debate focuses on the way securitizers should be required to retain an interest. Fender and Mitchell (2009b) show in a model-based analysis that sometimes holding more senior securities, such as the

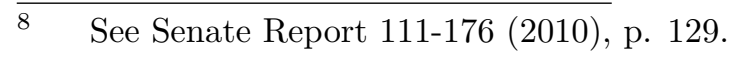


mezzanine tranche, or holding a vertical slice of all tranches may work best to align interests. Other authors promote strict retention of the first-loss piece as the best way for alignment of interests (Kiff and Kisser, 2010, 2012). The Board of Governors of the Federal Reserve System (2010) concludes that simple credit risk retention applied uniformly across assets of all type is unlikely to achieve an improvement of the securitization process. Instead, the board favors type-specific requirements that consider the different economics of different asset types. In this vein, my paper makes a contribution to the analysis of the economics of mortgage securitizations.

\section{Hypothesis Development}

Empirical research points to two primary motives for securitizations by banks and other firms. Banks undertake securitization transactions i) to obtain funding for their business activities and/or ii) to tailor risk resulting from their on-balance-sheet assets. My hypotheses build on these two motives for deriving the determinants of holding retained interest in securitized assets.

Under the funding motive, banks use securitization to convert illiquid loans into marketable securities in order to obtain cash proceeds from the investors in these securities. At the start of this process, banks select some of their assets, pool them and transfer them into a securitization vehicle. Usually, a bank has better information than investors with regard to the quality of the pooled assets (Franke and Krahnen, 2007; Franke et al., 2012). As a result, investors will only be willing to purchase the securities at a prohibitively low price because investors do not know whether the pooled assets are actually of high or low quality (Gorton and Pennacchi, 1995). This information asymmetry between banks and investors with regard to the quality of the securitized assets leads to adverse selection. To resolve this problem, banks must send a costly signal for the quality of the underlying assets. Landsman et al. (2008) suggest that holding retained interest in a pool of securitized assets is one way to signal the assets' quality. The signal should be the stronger, the lower the (perceived) quality of the pool of assets. Most often, banks securitize a part of their loan portfolio and the most important determinant of the quality of a loan is its underlying credit risk. Thus, in securitization of loans investors will assess the credit risk of the transferred loans. The higher their assessment of credit risk, the more costly must be the signal for the quality of the loans. This leads to the first hypothesis:

H1: Banks hold more retained interest when the securitized loans have higher credit 
risk, c.p.

Franke and Krahnen (2007) and Chen et al. (2008) among others argue that this signal for the (credit) quality of the securitized loans also serves as a means to protect investors against potential losses. Retained interest typically represents the first-loss (or equity) piece in a securitization transaction. If the pooled loans perform poorly, holders of retained interest will be the first to suffer losses. Holders of more senior interest are protected against losses as long as there is more junior interest to absorb losses. Thus, in a different explanation demand for retained interest would be due to investor demand for some form of protection against potential losses. The source of the potential losses can be adverse selection of the securitized loans. But the source can also be a moral hazard problem. Pennacchi (1988) and Gorton and Pennacchi (1995) suggest that when loans are transferred without any risk retention, banks would lack the incentive to produce an efficient level of credit information and monitoring. Both, adverse selection and moral hazard problems may then lead to high credit risk of the securitized loans. Since credit risk is one of the most important sources for potential losses, investors will demand more protection the higher the credit risk of the securitized loans.

These problems of information asymmetry may be mitigated when a bank has an established reputation for securitization transactions. Sufi (2007) and Ball et al. (2008) show in the context of syndicated loans that the bank which is the lead arranger retains less of a syndicated loan when it is more reputable. Franke et al. (2012) observe higher retained interest in securitizations of bonds than in securitizations of loans and presume that in the latter case orginators can reduce credit risk through loan monitoring. They suggest that investors anticipate a strong monitoring effort of the originator in securitizations of loans due to high reputation costs.

Such reputation considerations may force banks to pool primarily high quality loans, to provide implicit recourse to securitization structures, and to exert a reasonable amount of effort in loan screening and monitoring. Investors may therefore perceive securities as less risky when the securitizing bank has an established reputation. Banks will then be able to hold a smaller amount of retained interest. ${ }^{9}$ Thus, a

$9 \quad$ In contrast, investors may demand additional protection when a bank securitizes rarely or when it consummates a securitization transaction for the first time. For example, United Bankshares, Inc. only once securitized a pool of $\$ 205$ million in 1999 to better manage the risk from the underlying mortgages, see United Bankshares, Inc. (2000), p. 38. City Holding Company (not to be confused with Citibank) completed six securitization transactions between 1997 and 1999 with a volume of about $\$ 760$ million before terminating its securitization program in 1999 , 
banks' reputation and reputational concerns will act as a substitute for the signaling and/or protecting function of holding retained interest (Landsman et al., 2008). The second hypothesis reflects this role of reputation:

H2: Banks with an established reputation for securitization transactions hold less retained interest, c.p.

Reputational concerns can be merely abstract, meaning that a potential deterioration of reputation would not have any economic effect. However, a reputation for successful and smooth securitization transactions can well be of economic substance. Having an established reputation means that securitization transactions are repeated interactions with the market. When a bank relies on such repeated interactions to obtain funding, it will depend on the market's trust in its securitization products. A deterioriation of reputation may then lead to a loss of trust in the securitization products and a corresponding loss of funding. This may ultimately endanger the bank as a going concern.

The relative importance of securitization as a source of funding depends on a bank's capital structure. Banks which rely more on deposit-based financing should not be dependent on frequent securitization transactions to obtain funding. They should be more likely to conduct securitizations as rare transactions in order to transfer a group of particular assets from their balance sheet or to gain additional flexibility for their liquidity management. ${ }^{10}$

When a bank does not depend on securitization to obtain funding, it will be able to take more time for searching an investor in its asset-backed securities. It will also have a stronger position when negotiating the terms of the transaction. It might even be able to find a third-party investor which is willing to take the retained interest from the securitization transaction or which buys the retained interest shortly after the transaction. The portion of interest retained by a bank will thus be determined by the extent to which a bank is forced to complete the securitization transaction in the near term. An analysis of the determinants of retained interest should therefore control for

see City Holding Company (2002), p. 18. Republic Bancshares, Inc. securitized mortgages of $\$ 300$ million in 1997 and 1998 and had only limited securitization activity afterwards, see Republic Bancshares, Inc. (1999), p. 5. All these banks report rather high retained interest of between 4.3 percent and 99.0 percent of the outstanding securitized loan volume.

10 For example, Regions Financial Corporation securitized mortgages only in 1998 and 1999 amounting to a total volume of about $\$ 1.8$ billion. According to its 2001 annual report, these securitizations gave Regions additional flexibility for funding purposes, see Regions Financial Corporation (2002), p. 18. 
the extent to which a bank is forced to securitize. As this force is usually not directly observable, an analysis of the determinants of retained interest has to use proxy variables and should for example control for the relative importance of securitizationbased financing vs. other forms of funding, such as deposit-based financing. A-priori it is difficult to predict the sign of such control variables. Banks with a strong deposit base may be able to postpone the securitization transaction until market conditions are favorable or until they have found a third-party investor in the retained interest. This would lead to a negative relationship between deposit-based funding and the holding of retained interest. However, some banks with a strong deposit base might not be frequent securitizers. If a bank does not securitize frequently, investors could be sceptical about the quality of the assets underlying a securitization transaction. Investors would then demand the bank to hold additional retained interest in order to protect the investors against adverse selection and moral hazard problems. In this event, the relationship between deposit-based funding and retained interest could be positive. However, it seems likely that banks with a strong deposit base will take time to negotiate the terms of the transaction and to find investors willing to buy a part of the most risky tranches. For this reason, I expect a negative influence of a bank's deposit base on the amount of retained interest held.

Another control for the relative importance of securitization-based financing vs. other forms of funding would be the outstanding securitization volume. Banks which have securitized high volumes of assets are likely to complete securitization transactions frequently. It is likely that these banks have a routine for frequent and smooth securitization transactions. If investors appreciate such frequent and smooth securitization transactions, they might demand less retained interest held by the securitizing bank. This would yield a negative relationship between outstanding securitized volume and retained interest. In addition, some banks have - or better: had - a business model in which they acquire assets to securitize them immediately afterwards (Purnanandam, 2011). As part of this business model, the bank tries to sell the retained interest in the secondary market to obtain additional liquidity (Franke and Krahnen, 2008). Under this business model, there would also be a negative relationship between outstanding securitized volume and retained interest.

While one motive for securitization is the need for funding, academic research has shown that banks use securitization transactions also as a tool to tailor risk (Bannier and Hänsel, 2008; Panetta and Pozzolo, 2010). Under the risk tailoring motive, banks use securitization transactions to change their risk profile and feed their risk appetite. Banks are exposed to different types and degrees of risk depending on the assets (and 
liabilities) they hold. To change these exposures banks can use securitization and transfer some of the risks to another party. The effect on a bank's risk profile will depend on the type and degree of the risk transferred and on the type and amount of retained interest. Risk transfer via securitization does not necessarily lead to a lower risk exposure. Retained interest often represents a form of concentrated risk, in particular if the first-loss piece is retained (see SFAS 140.59; Chen et al., 2008).

Such concentrated risk exposures might be very complex. For managing and evaluating these exposures banks need to monitor prepayment speeds, discount rates and rates of delinquency and default. Banks need also adequate valuation models, which can be quite complex. Thus, monitoring retained interest can be a challenging task for a bank's risk management and it will usually be easier for more sophisticated banks, such as large universal banks, to manage this task. Banks that already have a good capability for managing interest rate risk, credit risk and other types of risk will be better able to manage risk exposure from retained interest. Therefore, more sophisticated banks might be willing to hold more retained interest. This leads to the third hypothesis:

H3: More sophisticated banks hold more retained interest, c.p.

Taking risk is part of the normal business of banks. Almost all assets held by a bank are more or less subject to different types of risk. The willingness to take risk is determined by a bank's risk appetite. Therefore, the willingness to hold a concentrated risk exposure from retained interest will also depend on a bank's risk appetite. Apart from retained interest, banks have risk exposures from other assets such as loans. Existing exposures from other assets will have an impact on a bank's risk appetite. This impact on a bank's risk appetite will also affect the bank's willingness to take risk from retained interest. Consistent with this view, Casu et al. (2011) document a negative relationship between banks' outstanding securitization volumes and banks' risk taking from other activities. Therefore, the amount of retained interest held by a bank will be affected by its current risk exposure. If a bank is already exposed to high risk, it will be less willing to accept additional or concentrated risk in the form of retained interest.

For most banks, credit risk will be the most important type of risk (Herring and Schuermann, 2005) and loans will be the largest and most obvious source of credit risk (BCBS, 2000). Therefore, credit risk from loans will have the most important impact on a bank's risk appetite. In particular, the exposure to credit risk from loans should determine the remaining appetite for risk from other assets. If a bank has a high 
exposure to credit risk from its loans, it will be less willing to take additional risk, such as a concentrated risk position from retained interest. The fourth hypothesis takes this into account:

H4: Banks hold less retained interest when they are exposed to higher credit risk from their on-balance-sheet loans, c.p.

Put differently, banks with overall low risk can afford to take more risk from securitizations and can afford to hold more retained interest. Banks in a stable position will be less affected by potential losses from retained interest. They will be able to meet investor demand for retained interest more easily and will have less of an incentive to sell retained interest after the securitization transaction.

\section{Sample Selection and Research Design}

\subsection{Data}

One of the key challenges when analyzing securitization transactions is data availability. Information about securitization transactions is not available from annual or quarterly financial statements in a standardized form. Collection of such information is a cumbersome task and often requires substantial judgement from researchers when standardizing the data provided. For this reason, the data used for the empirical analysis in this paper are obtained from FR Y-9C reports (bank holding company reports). Bank holding companies have to file these reports when they have total consolidated assets of $\$ 500$ million or more or meet certain other criteria. ${ }^{11}$ The reports are filed quarterly on a consolidated basis with the Federal Reserve. Since 2001 these reports require detailed information about banks' securitization activities, including information about retained interest and delinquencies of securitized loans. In line with related papers, I restrict my sample period to the years 2001 to 2006, in order to exclude the onset of the financial crisis from the sample period. ${ }^{12}$ Because of this restriction, it should be unlikely that observations are affected by crisis-related effects.

In the FR Y-9C report, bank holding companies have to state the outstanding principal balance of securitized assets for which servicing has been retained or for

11 The threshold of $\$ 500$ million has been effective since 2006 . In the period before, the threshold for the filing requirement was $\$ 150$ million.

12 See e.g. Chen et al. (2008); Barth et al. (2012) who also limit their sample period to 2001 to 2006. 
which recourse or some other form of credit enhancement has been provided by the bank. The relevant schedule on securitization activities is to be completed on a fully consolidated basis and includes only information on securitized assets that are not reportable on the bank's consolidated balance sheet. ${ }^{13}$ Securitized assets are disaggregated into seven classes of assets. For this paper, the class of interest is "1-4 Family Residential Loans" which is commonly known as mortgages. The reported amounts exclude mortgages sold to the Federal National Mortgage Association (Fannie Mae) or the Federal Home Loan Mortgage Corporation (Freddie Mac). Therefore, the focus of this paper is on so called non-agency or private-label securitizations which represent a major subgroup of all securitizations with an annual issuance volume of about $\$ 900$ billion during the boom period of 2005 to $2006 .^{14}$

For the empirical analysis, I select only banks that report a non-zero balance of outstanding securitized mortgages ${ }^{15}$ and exlude all other banks. In order to remove subgroups, I exclude all banks that are controlled by another bank as indicated by the highest holder identifier (data item RSSD9348). I truncate obvervations of continuous variables at the 99 th percentile to mitigate the effect of outliers. ${ }^{16}$ For scaling income and expense items, I use net interest income. To prevent descriptive statistics from being biased by outliers, I set net interest income to missing in quarters when it is negative. ${ }^{17}$ This procedure leads to a final sample of 1,355 firm-quarter observations from 164 bank holding companies.

Information on a bank holding company's reputation is taken from The 2010 Mortgage Market Statistical Annual by Inside Mortgage Finance. The annual includes a list of the top 25 issuers of non-agency mortgage-backed securities for every year of the sample period. Consistent with studies on loan syndication, ${ }^{18}$ I consider a bank to have an established reputation for securitization transactions if it has been among the top 25 issuers during the sample period.

13 See Board of Governors of the Federal Reserve System (2001), HC-S-1.

14 See SIFMA (2012b).

15 In March 2002 the filing instructions for the FR Y-9C report clarified that securitizations that have been accounted for as secured borrowings are to be excluded from the outstanding principal balance of securitized mortgages and should continue to be carried as assets on the balance sheet (Board of Governors of the Federal Reserve System, 2002a; HC-S-3). So the securitized mortgages in my sample include only mortgages that are not (longer) reported on the balance sheet.

16 Results remain substantially unaffected if the truncation level is set to $99.5 \%$ or to $97.5 \%$ or if the lower bound of the variables is also truncated.

17 This procedure eliminates scaled income and expense observations for two banks. It does not affect the results of the multivariate analysis, because the multivariate analysis does not use income and expense items.

18 See e.g. Ball et al. (2008). 


\subsection{Empirical Design}

Besides information about the amount of outstanding securitized mortgages, FR Y-9C reports provide information about the nature and amount of recourse or other credit enhancements provided in securitization transactions. In particular, the schedule on securitization activities shows the maximum amount of credit exposure arising from retained interst-only strips, from standby letters of credit, and from subordinated securities and other enhancements. A separate line item discloses the unused portion of a bank's commitments to provide liquidity to securitization structures. For the empirical analysis, I construct my dependent variable Retained Interest as the total of all these types of recourse or other enhancements provided in mortgage securitizations and scale the total by the bank's amount of outstanding securitized mortgages. ${ }^{19}$

Information about most of the determinants of retained interest is also obtained from the FR Y-9C reports. The variable for credit risk of the securitized mortgages is Delinquent Securitized Mortgages. It is measured as the past due loan amount of securitized mortgages scaled by the bank's outstanding securitized mortgages.

A bank's level of sophistication is usually difficult to measure. Liu et al. (2004) note that "[m]ore technically sophisticated banks typically have larger trading portfolios and may manage their trading and non-trading exposures differently than other banks." Bank regulation requires bank holding companies with signifcant trading activities to have a sophisticated risk management system. The Federal Reserve's minimum requirements for the risk management system include a risk control unit that reports directly to senior management, a risk measurement model that is integrated into the daily management process, appropriate stress tests and backtests and regular reviews of the risk management system. ${ }^{20}$ Therefore, banks with a significant portion of trading assets can be expected to be more technically sophisticated. In particular, trading assets often comprise derivatives, which may require a sophisticated risk management system. Accordingly, I use the variable Trading Assets, measured as trading assets scaled by total assets, as a proxy for the level of sophistication of a bank. ${ }^{21}$

19 Scaling by the amount of oustanding securitized mortgages requires that the amount of outstanding securitized mortgages is non-zero because scaling by zero is not possible.

20 See Code of Federal Regulations (2012), Title 12, Pt. 225, App. E.

21 A possible issue with using trading assets as a proxy for the level of sophistication is that results may be biased towards my hypothesis. Such a bias may follow if banks tend to classify retained interest as trading assets. However, untabulated comparisons of retained interest with trading assets show that retained interest is usually much smaller than trading assets. On average, retained interest has only 21.7 percent of the size of trading assets, with a median of 0.0 percent. An additional analysis of sample banks' annual reports showed that only 15 percent of banks classify retained interest as trading securities. So it seems unlikely that classification of retained 
For measuring credit risk from on-balance-sheet loans, I follow the approach in other studies (e.g. Wahlen, 1995; Beaver and Engel, 1996; Harris et al., 2013) and measure credit risk by Non Performing Loans. This variable is defined as the total of loans and leases 90 or more days past due and loans and leases on nonaccrual status scaled by the total of all loans and leases.

The dummy variable High Reputation indicates whether a bank has an established reputation for securitization transactions. It is one if the bank holding company or one of its subsidiaries has been among the top 25 issuers of non-agency mortgage-backed securities in the years 2001 to 2006 and zero otherwise.

Total Assets is the natural logarithm of a bank's total assets in thousand US-\$. I include this variable to control for any structural differences that could be related to size.

To control for the relative importance of securitization-based financing vs. other forms of funding, I include two additional variables. Deposits is the total of the bank's domestic and foreign deposits scaled by total assets. It measures the strength of the bank's deposits base and thus its independence from securitization transactions as a source of funding. Outstanding Securitized Mortgages is the bank's outstanding principal balance of mortgages securitized for which servicing or recourse or other credit enhancements have been retained. It is scaled by total assets and indicates whether the bank has securitized a high volume of assets and might therefore have a routine for frequent and smooth securitization transactions or whether the bank has a business model under which it primarily acquires assets to securitize them.

In the empirical analysis, I use panel regression techniques to estimate the relation between retained interest and my measures of credit risk, reputation, sophistication and exposure to risk from on-balance-sheet loans. The base model is:

$$
\begin{aligned}
\text { Retained Interest }_{i t}= & \beta_{0}+\beta_{1}{\text { Delinquent Securitized } \text { Mortgages }_{i t}} \\
& +\beta_{2} \text { High Reputation }+\beta_{3} \text { Trading Asset }_{i t} \\
& +\beta_{4} \text { Non Performing Loans } s_{i t}+\gamma \text { Controls }_{i t}+\epsilon_{i t}
\end{aligned}
$$

I start with fixed-effects regressions to control for unobserved fixed heterogeneity across sample banks. High Reputation is identified as a dummy variable that does not vary over time and thus is by definition a fixed effect. For this reason, I run

interest as trading assets drives the results. 
random-effects regressions for all specifications of the model that include the dummy High Reputation.

\section{Results}

\subsection{Univariate Analysis}

Table 1 presents the distribution of total retained interest, of the components of retained interest and of the bank- and loan-specific variables which are used as proxies for the determinants of retained interest. The mean bank has Retained Interest of 4.4 percent of its outstanding securitized mortgages. The median of Retained Interest is only 0.0 percent. These results are somewhat smaller than the level of retention reported by Chen et al. (2008). However, in their study the authors use a different sample selection procedure and report winsorized rather than truncated data. The distribution of Retained Interest is more similar to Chen et al. (2008) when I also winsorize the data.

Subordinated ABS, standby letters of credit and other enhancements are the largest component of Retained Interest with a mean (median) of 3.2 (0.0) percent. In the FR Y-9C reporting form, this aggregate class of retained interest was split into two separate classes in December 2003. Accordingly, the number of observations for these two separate classes is lower. The disaggregation shows that subordinated ABS are the most important type of retained interest with a mean (median) of $2.0(0.0)$ percent.

A large fraction of sample banks do not report any retained interest at all. This result is unexpected, because banks should have to retain interest in securitized mortgages due to the information asymmetry problems discussed in Section 3. A large fraction of observations with zero retained interest might raise some technical issues in the regression analysis, therefore the sensitivity analysis in Subsection 5.4 will deal with this finding in more detail.

\section{[Insert Table 1 here]}

Table 1 also reports the distribution of the bank- and loan-specific variables which are used as proxies for the determinants of retained interest. On average (median), 2.7 (0.1) percent of outstanding securitized mortgages are delinquent, i.e. contractual payments on these mortgages are due and unpaid for 30 days or more. Among the five percent of sample banks with the highest portion of delinquent mortgages is e.g. 
Provident Financial Group. This bank is chosen as an example because it documented its securitization activities well in its $10-\mathrm{K}$ statement and amounts can easily be compared to the FR Y-9C report. For the year ended December 31, 2001, Provident presented a value of 23.27 percent of Delinquent Securitized Mortgages. This was accompanied by a value of Retained Interest of 11.62 percent, which is well above the average retained interest reported in the sample. ${ }^{22}$ The observation of a high portion of delinquent mortgages, my measure of credit risk, and a high portion of retained interest is in line with the argument expressed in Hypothesis 1 that banks hold more retained interest when the securitized mortgages have higher credit risk.

High Reputation has a mean of 12.8 percent. This is the portion of sample banks which belong to the top 25 issuers of non-agency mortgage-backed securities and are considered as having a high reputation for securitization transactions. Trading Assets have a mean (median) of $1.3(0.0)$ percent. Overall, this asset class is of minor importance. For example, Provident Financial Group reports trading assets to total assets of only 0.6 percent, which is still above the 70th percentile. However, the bank explains in its $10-\mathrm{K}$ statement that

Provident enters into swaps to synthetically alter the repricing characteristics of specific assets, liabilities and off-balance sheet loan securitizations. ${ }^{23}$

So, there is some anecdotal evidence that banks actively manage the risk arising from securitizations. Derivatives are a common tool for risk management and derivatives are included in trading assets. These assets require a sophisticated system for risk measuring and monitoring. This supports the approach to use Trading Assets as the proxy for the level of a bank's sophistication.

Mean (median) Non Performing Loans are 1.0 (0.8) percent. These figures generally compare to prior studies (e.g. Cantrell et al., 2013; Harris et al., 2013). Sample banks vary substantially with regard to size and their funding models. The average (median) bank has total assets of $\$ 4,561(\$ 5,032)$ million. ${ }^{24}$ Deposits are the most important source of funding with a mean (median) of 68.8 (71.0) percent of total

22 In its 10-K statement for the year ended December 31, 2001, Provident Financial Group discloses a ratio of mortgages 90 days or more delinquent to total managed assets, which is 13.85 percent. In the FR Y-9C report the ratio of mortgages 90 days or more delinquent to outstanding securitized mortgages is 16.09 percent. Explanations for the difference of 2.24 percent include differences in the numerator, which may include delinquent amounts from other managed - but not securitized - assets in the $10-\mathrm{K}$ statement, and differences in the denominator, which is not the amount of outstanding securitized mortgages in the 10-K statement. See Provident Financial Group, Inc. (2002), p. 62.

23 See Provident Financial Group, Inc. (2002), p. 63.

24 The variable Total Assets is measured as the natural logarithm of total assets in thousand US-\$. A value of 15.333 corresponds to $e^{15.333}=\$ 4,560,760$ thousand or $\$ 4,561$ million. 
assets. The bank with the smallest observation of Deposits is Countrywide Financial Corporation with a value of 7.7 percent in March 2003. Countrywide funded its operations primarily through securitization transactions. It is also the bank with the highest value of Outstanding Securitized Mortgages with a ratio of 259.3 percent of securitized mortgages to total assets in June 2006. This is much larger than the mean (median) of Outstanding Securitized Mortgages, which is only 13.8 (3.1) percent. The bank with the maximum value of Deposits is Commerce Bancorp, Inc. For this bank, deposits are 90.6 percent of total assets in September 2001.

The substantial variation with regard to the asset and funding structure of sample banks is the result of different business models and might also affect the level of retained interest held by a bank. In order to capture differences in the holding of retained interest across different business models, I perform a $k$-means cluster analysis to define different groups of banks according to their business model. The variables that I use for clustering control for the different asset and funding structures of banks. In particular, I use on-balance-sheet mortgages, consumer loans, commercial and other loans, securities, trading assets and deposits, all of which are scaled by total assets. I also use the securitization ratio as a clustering variable, which is the ratio of the bank's outstanding securitized mortgages divided by on-balance-sheet mortgages. This ratio helps to identify banks which primarily acquire mortgages in order to securitize them immediately afterwards.

The clustering procedure results in four different types of banks: originate-todistribute (OTD) banks, universal banks, diversified commercial banks, and traditional commercial banks. Table 2 presents descriptive statistics for bank- and loan specific variables by bank type. OTD banks have an originate-to-distribute business model under which they originate or purchase mortgages in order to securitize them immediately afterwards (Purnanandam, 2011). Examples of OTD banks include Countrywide and Doral Financial Corporation. These banks are large with mean total assets of $\$ 81.90$ billion. ${ }^{25}$ Mortgages represent on average 41 percent of the assets of these banks. Consistent with the originate-to-distribute business model, OTD banks have the highest portion of Loans Held for Sale with 17 percent on average. These banks also have the highest portion of trading assets with a mean of 7 percent. With regard to their funding strategy, OTD banks rely primarily on short-term liabilities, such as repurchase agreements and federal funds purchased with a mean of 23 percent or Other Liabilities with a mean of 28 percent. Deposits are of relatively minor importance for OTD banks when compared with other types of banks. The mean of Deposits is

$25 \quad$ For ease of presentation I do not discuss median values here 
only 36 percent for OTD banks. The loan portfolio of these banks appears riskier than those of other bank types, because Non Performing Loans are on average higher with 2 percent of total loans. OTD banks generate primarily noninterest income from securitization transactions and the sale of loans. 53 percent of OTD banks have an established reputation for securitization transactions. On average, these banks have outstanding securitized mortgages of 3.31 times their on-balance-sheet mortgages and of 1.37 times their total assets. The mean of mortgages that these banks service for another party is 2.19 times their total assets. These values reflect the nature of the OTD business model. It also seems that OTD banks securitize particularly risky mortgages. The mean of mortgages that are 30 or more days past due is 6 percent of outstanding securitized mortgages. Despite the relatively high risk of the securitized mortgages, OTD banks hold on average only 3 percent Retained Interest, which is smaller than the mean of Retained Interest for the entire sample. There are two explanations for this observation of relatively low Retained Interest. First, OTD banks often have an established reputation for securitization transactions and are therefore able to hold less retained interest. Second, OTD banks sell retained interest to the secondary market (Franke and Krahnen, 2008; Fender and Mitchell, 2009b).

\section{[Insert Table 2 here]}

The second type of banks are universal banks, which are the largest banks with a mean of total assets of $\$ 154.64$ billion. Universal banks invest in different asset classes such as mortgages with on average 31 percent, commercial and other loans with on average 16 percent, and securities with on average 28 percent of total assets. The mean of Trading Assets is 3 percent for universal banks, which is well above the average for the entire sample. The funding structure of universal banks relies more on deposits, which represent on average 58 percent of total assets. Short-term liabilities like Repos $\&$ FedFunds Purchased or Other Liabilities are significantly smaller than for OTD banks with means of 11 percent and 17 percent, respectively. Net interest income is slightly higher for universal banks than for OTD banks with a mean of 9 percent of book value of equity. At the same time, universal banks generate significant noninterest income, which is on average 71 percent of net interest income. The different sources of income for universal banks show the sophistication of these banks. Universal banks generate a part of their income from sophisticated business activities, such as investment banking with a mean of 19 percent or trading with a mean of 3 percent of net interest income. Other activities like servicing (mean: 2 percent), securitization transactions (mean: 2 percent) and loan sales (mean: 2 percent) are also important sources of income. Securitization transactions do not 
appear as a major source of funding for these banks. The Securitization Ratio has a mean of 11 percent, Mortgages Serviced for Others has a mean of 9 percent and Outstanding Securitized Mortgages has a mean of 3 percent. 21 percent of universal banks have an established reputation for securitization transactions. Universal banks securitize slightly riskier mortgages. The mean of Delinquent Securitized Mortgages is 4 percent, which is above the value for the entire sample. Universal banks hold the highest portion of retained interest with a mean of 9 percent of outstanding securitized mortgages. This high level of retained interest might be driven by the credit risk of the securitized mortgages. However, when compared to the retained interest held by OTD banks, it seems likely that universal banks do not only hold retained interest because of the credit risk of their securitized mortgages. It might be possible that large, sophisticated banks are more willing to hold retained interest because they are better able to manage the risk from these positions.

The third type of banks are diversified commercial banks. These banks invest into different asset classes like mortgages with a mean of 39 percent, commercial and other loans with a mean of 13 percent and securities with a mean of 25 percent of total assets. For their funding, diversified commercial banks rely primarily on deposits with a mean of 67 percent, but they also use securitization transactions on a large scale, so that Outstanding Securitized Mortgages have a mean of 30 percent. As a result of their diversified business activities, these banks generate a significant part of their income from sophisticated activities like trading with a mean of 5 percent or investment banking and brokerage services with 17 percent of net interest income. Income from servicing (mean: 4 percent) and from the sale of loans (mean: 7 percent) are more important than for universal banks. It seems that diversified commercial banks perform securitization transactions to obtain additional funding flexibility. The Securitization Ratio has a mean of 78 percent, while Mortgages Serviced for Others are on average 61 percent. The credit risk of the securitized mortgages is below average with a mean of 2 percent for Delinquent Securitized Mortgages. Diversified commercial banks hold below average retained interest with a mean of 2 percent of oustanding securitized mortgages. The explanation for this below-average level of retained interest could be the below-average credit risk of the securitized mortgages and the established reputation of these banks for securitization transactions. High Reputation has a mean of 25 percent.

The fourth type of banks are traditional commercial banks. These banks have the highest portion of mortgage loans with a mean of 51 percent of total assets. Securities with a mean of 19 percent and Trading Assets with a mean of 0 percent are substantially smaller than for all other types of banks. At the same time, traditional commercial 
banks are almost completely funded by deposits which represent on average 75 percent of total assets. All other sources of funding, including securitization transactions, are less important. Total Noninterest Income is much smaller than for all other banks with a mean of 37 percent. Servicing Income has a mean of 1 percent and Securitization Income has a mean of 0 percent. It appears that traditional commercial banks use securitization transactions only as a tool to tailor their risk profile and not as a source of funding. Consistently, only 3 percent of traditional commercial banks have an established reputation for securitization transactions, the Securitization Ratio is on average only 7 percent and outstanding securitized mortgages represent on avergage only 4 percent of total assets. Traditional commercial banks securitize less risky mortgages, the mean of Delinquent Securitized Mortgages is 2 percent. Surprisingly, Retained Interest is 4 percent in the mean, but only 0 percent in the median. The distribution of Retained Interest for these banks is skewed by a few outliers, which hold a high percentage of Retained Interest from securitization transactions that had only insignificant volumes. The explanation for this high percentage of Retained Interest could be that these banks do not have an established reputation for securitization transactions and, therefore, investors are sceptical about the quality of the securitized mortgages despite average low Delinquent Securitized Mortgages. ${ }^{26}$

Table 3 presents Pearson correlations coefficients for the dependent variable and the bank- and loan-specific characteristics. As expected, Retained Interest is positively correlated with the measure of credit risk, Delinquent Securitized Mortgages. Contrary to the argument discussed in the hypothesis development, Retained Interest is weakly positively correlated with the measure of bank reputation. However, there is a strong positive correlation between reputation and bank size (coefficient of 0.587), which might influence the correlation between Retained Interest and High Reputation in a univariate analysis. The correlation of Retained Interest and the proxy for banks' sophistication, Trading Assets, is positive as expected. The correlation of Retained Interest and Non Performing Loans is positive, but not significantly different from zero. It seems that, in a univariate analysis, risk exposure from other assets does not have a strong influence on the amount of Retained Interest held. Results may differ when in a multivariate analysis other factors are controlled for. There is also a positive correlation between Retained Interest and Total Assets, indicating that larger banks hold more retained interest. The correlations of Retained Interest with each of

$\overline{26}$ It is also possible that these banks use QSPEs in their securitization structures and initially retain all of the securities that result from the securitization transactions. The banks then sell the securities when market conditions are favorable. 
the two control variables for a bank's funding structure, Deposits and Outstanding Securitized Mortgages, are negative as expected.

\section{[Insert Table 3 here]}

\subsection{Multivariate Analysis}

To be conservative, I evaluate significance using two-tailed tests despite the fact that my hypotheses are directional. In a two-tailed test, a 10 percent significance level corresponds to a 5 percent significance level in a one-tailed test.

Table 4 presents results for regressions of Retained Interest on bank- and loanspecific characteristics. Each regression is a different specification of Model 1, the base model. The line under the specification number indicates whether the specification is a fixed-effects ("FE") or random-effects ("RE") regression. In every specification, standard errors are clustered at the firm level and quarter-fixed effects are included.

Regression (1) examines only the effect of credit risk of the securitized mortgages and controls on Retained Interest. The coefficient on Delinquent Securitized Mortgages is 0.632 . It is positive and significant at the 10 percent level. This results is in line with Hypothesis 1 and provides some first evidence that banks hold more retained interest when the securitized mortgages have higher credit risk. The signs of the control variables are also in line with the predictions derived in the hypothesis development, but the coefficients are not statistically different from zero.

In order to gauge the economic significance of the relation between Delinquent Securitized Mortgages and Retained Interest, I draw on the estimates of Regression (1). The mean bank has Delinquent Securitized Mortgages of 2.7 percent. Given a coefficient estimate of 0.632 for this variable, the mean bank has to hold Retained Interest of about 1.7 percent due to the portion of delinquent mortgages among its outstanding securitized mortgages. ${ }^{27}$

Regression (2) includes High Reputation as an additional explanatory variable and reports the estimates from a random-effects model. In the definition that I use the dummy for bank reputation is time-invariant and cannot be included in a fixed-effects model. The coefficient on High Reputation is negative, but not significant in this specification. This result provides only weak evidence for Hypothesis 2 that banks with an established reputation for securitization transactions hold less retained interest. However, the result becomes stronger in the subsequent specifications. The

$27 \quad$ The amount of Retained Interest for the mean bank equals 0.027 (mean of Delinquent Securitized Mortgages) x 0.632 (coefficient estimate) $=0.017064$. 
coefficient on Delinquent Securitized Mortgages is slightly larger than in Regression (1) and is now significant at the 1 percent level.

Regression (3) introduces Trading Assets as the measure of bank sophistication into the regression. Although the estimated coefficient is not significant at conventional levels ( $p$-value 0.164 ), it is positive as predicted in Hypothesis 3. To the extent that the portion of trading assets is a valid proxy for the sophistication of a bank, it seems that more sophisticated banks with a better ability to manage risk are willing to hold more retained interest. The coefficient on Delinquent Securitized Mortgages is again positive and significant at the 1 percent level. The magnitude of the coefficient on High Reputation increases and the coefficient is now significantly negative at the 5 percent level, which supports the argument that banks with an established reputation hold less retained interest. The control variables have the same sign as in the previous two specifications, but are statistically insignifcant.

Regression (4) includes the measure of risk exposure arising from other assets, Non Performing Loans. The coefficient is negative and significant at the 5 percent level. This result is consistent with Hypothesis 4 and suggests a negative relationship between retained interest and risk exposure from other assets. This observation is different from the result in the univariate analysis, which reported a weakly positive correlation coefficient between Retained Interest and Non Performing Loans, but which did not control for other factors. In addition, the coefficient on Delinquent Securitized Mortgages is significantly positive at the 1 percent level and the coefficient

on High Reputation is significantly negative at the 5 percent level. For trading assets the estimated coefficient is slightly larger than in the previous specification and is now close to significance at conventional levels ( $p$-value 0.124$)$. This specification of Model 1 has an Overall $R^{2}$ of 18.0 percent and a $C h i^{2}$-statistic of 100.696 which indicate that the model has reasonable explanatory power for the amount of retained interest held from mortgage securitizations.

\section{[Insert Table 4 here]}

An alternative explanation for the positive association of Retained Interest and Trading Assets could be that the positive coefficient on Trading Assets is simply the result of differences in the business model of banks. In order to control for the effect of different business models, Regression (5) introduces dummy variables for the different types of banks. The dummy variables are based on the types of banks defined in Subsection 5.1. Traditional commercial banks are the benchmark group in this specification. The estimated coefficients on the dummy variables are in line with the observations in Subsection 5.1. In particular, OTD banks seem to hold a relatively 
small amount of retained interest, while universal banks seem to hold a larger fraction of the interest in the securitized mortgages. Diversified commercial banks hold on average less retained interest. However, none of the estimated coefficients for the dummy variables is significant. More importantly, introducing the dummy variables for banks' business models does not materially change the coefficients and significance levels of Delinquent Securitized Mortgages, High Reputation and Non Performing Loans. The coefficient on Trading Assets even increases and is only marginally insignificant ( $p$-value 0.111). Therefore, it seems that the positive association between Retained Interest and Trading Assets is not driven by differences across banks' business models. This result supports the interpretation that Trading Assets is a proxy for the bank's level of sophistication and that bank sophistication is positively associated with the amount of retained interest held.

Finally, Regression (6) reports estimates for a fixed-effects model that excludes all dummy variables. This specification serves as a sensitivity check of the results to any unobserved fixed-effects. The coefficient on Delinquent Securitized Mortgages is now 0.678 , which is slightly smaller than the coefficients estimated in the random-effects Regressions (2) to (5). The coefficient is significant at the 5 percent level. This result provides further support for Hypohesis 1 that credit risk of the securitized assets is positively associated with the amount of retained interest held. The coefficient on Trading Assets is 0.844, which is larger than in the previous specifications. It has the predicted positive sign and is now significant at the 1 percent level. Therefore, it seems that there are some unobserved fixed effects which in the random-effects regressions bias the coefficient on Trading Assets downwards. The results from the fixed-effects regression provide additional evidence that more sophisticated banks hold more retained interest. Risk exposure from other assets, as measured by Non Performing Loans continues to have a negative association with the amount of retained interest held. The coefficient is -1.545 and is significant at the 5 percent level.

\subsection{Analysis of Additional Determinants}

\subsubsection{Earnings Management}

Some studies have analyzed the potential and use of securitization transactions for earnings management (see e.g. Bryan et al., 2010). Karaoglu (2005) provides evidence that banks use gains from securitization transactions to smooth earnings. However, it is unclear whether securitizations are an effective tool for earnings management. In Karaoglu (2005) income from securitization transactions has a mean (median) of 0.20 percent (0.06 percent) of total regulatory capital. In my study, Table 2 reports 
a mean (median) for income from securitization transactions scaled by net interest income of 7 percent (2 percent) for OTD banks, for all other banks it is substantially smaller. It does not seem likely that these relatively small amounts help much to smooth earnings.

Dechow and Shakespeare (2009) report that most securitization transactions occur at the end of a quarter and suggest that window-dressing the financial statements appears to be a valuable side-benefit of securitization transactions. Dechow et al. (2010) investigate whether for firms with strong corporate governance mechanisms CEO compensation is less sensitive to securitization income than to other sources of income and do not find that better "monitoring" reduces earnings management. However, as Barth and Taylor (2010) note, the reason for the observation of earnings management in Dechow et al. (2010) could be a mechanical negative correlation between securitization income and net income before securitization income for firms that use securitization transactions on a large scale. If a firm earns most of its income from securitization transactions, it is likely that its net income before securitization income will be negative.

To address incentives for earnings management in securitization transactions, I extend Model 1 to include indicators for earnings management. Model 2 shows the model for the analysis of earnings management incentives:

$$
\begin{aligned}
\text { Retained Interest }_{i t}= & \beta_{0}+\beta_{1} \text { Delinquent Securitized Mortgages }_{i t} \\
& +\beta_{2} \text { High Reputation }+\beta_{3} \text { Trading Asset }_{i t} \\
& +\beta_{4} \text { Non Performing Loans } \text { It }_{i}+\gamma \text { Controls }_{i t} \\
& +\delta \text { D.EM } \epsilon_{i t}
\end{aligned}
$$

D.EM represents a dummy variable that indicates incentives for earnings management in a given bank-quarter. I use six different dummy variables that capture different situations in which banks may have an incentive to engage in earnings management, in particular in earnings smoothing. Table 5 shows descriptive statistics for the dummy variables. D.Loss before SecInc is one if net income before securitization income is negative and zero otherwise. When managers face a loss from net income before securitization income, they have an incentive to perform additional securitization transactions or to overstate the value of retained interest. If managers smooth reported net income by overstating retained interest in quarters with a negative net income before securitization income, the value of retained interest in such quarters should be higher than in other quarters. In the presence of earnings smoothing, the 
coefficient of D.Loss before SecInc should therefore be positive.

D.Loss Avoided is one if net income before securitization income is negative and, at the same time, net income after securitization income is positive and zero otherwise. This dummy indicates bank-quarters where securitization income was sufficient to turn a pre-securitization loss into a post-securitization profit. If managers avoid the loss by overstating the retained interest from securitization transactions, this dummy should have a positive coefficient.

D.Quarterly (Annual) Decrease before SecInc is one if net income before securitization income has decreased from the prior quarter (the prior year's quarter) to the current quarter and zero otherwise. Burgstahler and Dichev (1997) provide evidence that firms manage reported net income to avoid decreases of net income. Net income from the prior quarter (prior year's quarter) usually represents a benchmark that managers would like to beat. If managers overstate retained interest from securitization transactions to smooth decreases of net income, the coefficient of this dummy should be positive.

Similarly, D.Quarterly (Annual) Decrease Avoided is one if net income before securitization income has decreased from the prior quarter (prior year's quarter) to the current quarter and net income after securitization income has increased and zero otherwise. This dummy indicates bank-quarters where securitization income was sufficient to avoid a decrease of net income. In the presence of earnings smoothing, the coefficient of this dummy should be positive.

Table 6 presents results from random-effects regressions of Model 2 using the different dummies for earnings management incentives. The estimated coefficients for the other explanatory variables remain substantially the same as in Regression (4) of Table 4. However, the estimated coefficients on the earnings management indicators are all insignificant. The coefficients on D.Loss before SecInc, D.Loss Avoided, D.Quarterly Decrease before SecInc, D. Annual Decrease before SecInc and D.Annual Decrease Avoided are negative, which is contrary to the predicted incentives for earnings smoothing in these bank-quarters. Only the coefficient on D.Quarterly Decrease Avoided havs the expected positive sign, but it is statistically not different from zero ( $p$-value 0.572 ).

Overall, I do not find evidence for earnings management through overstating the value of retained interest from securitization transactions. This result is consistent with average small securitization income that generally does not help much to smooth net income. 


\subsubsection{Regulatory Arbitrage}

Some authors (e.g. Calomiris and Mason, 2004) argue that banks engage in securitization transactions to lower their risk-weighted assets in order to achieve relief for their regulatory capital. This behavior is usually referred to as regulatory arbitrage. Such regulatory arbitrage is successful if the regulatory capital requirement after the securitization transaction is lower then it was before. The net impact on the regulatory capital requirement depends on the treatment of the specific securitization transaction for regulatory capital purposes. This treatment is complex. It depends on the type of exposure that the bank retains as a result of the credit enhancement provided to the transaction. ${ }^{28}$

The Federal Reserve's regulatory capital guidelines distinguish between those exposures that qualify for the ratings-based approach and those exposures that do not qualify. Generally speaking, an exposure qualifies for the ratings-based approach if it receives an external rating. For those exposures that qualify for the ratingsbased approach, the required amount of risk-based capital is determined based on the relative risk of the exposure as measured by the rating category. For all other exposures, the regulatory capital guidelines distinguish between exposures in the form of on-balance-sheet assets ${ }^{29}$ and exposures that do not result in on-balance-sheet assets (e.g., recourse obligations which may have an associated on-balance-sheet liability). All exposures in the form of on-balance-sheet assets are subject to a dollar-for-dollar requirement of risk-based capital. For all other forms of exposure, the low-level exposure rule applies. According to this rule, the required risk-based capital is the lesser of i) the maximum contractual loss that could result from the exposure less any associated recourse liability, or ii) the risk-based capital required to be held against the outstanding securitized assets if they were still on the bank's balance sheet.

Retained interest represents the first-loss piece in a securitization transaction. This tranche is subordinated to all other tranches and often is not rated. For this reason, most retained interest should not be eligible for the ratings-based approach. Moreover, Table 1 shows that retained interest is most often in the form of subordinated ABS, i.e. retained interest is most often an on-balance-sheet asset. Therefore, retained interest is subject to a dollar-for-dollar charge to risk-based capital.

Given that retained interest should generally be subject to a dollar-for-dollar

28 See Board of Governors of the Federal Reserve System (2002b), GL-53, for a summary of the regulatory capital treatment.

29 The regulatory capital guidelines use the term residual interest which is more narrow than the term retained interest used in this paper; see Board of Governors of the Federal Reserve System (2002a), H-C-21 and 22. 
charge to risk-based capital, securitizers should have an incentive to retain less interest when they are less capitalized. However, in untabulated regressions there is no systematic association between the level of retained interest and the risk-based capital ratios. One possible explanation might be that banks achieve net capital relief by entering into the securitization transactions. When regulatory capital is released for the securitized assets, the net impact after taking into account the capital requirement for retained interst can still be positive for banks. This may lead to an ambiguous influence of regulatory capital considerations on the level of retained interest.

\subsection{Sensitivity Analysis}

A large fraction of sample banks do not report any retained interest at all. This result is unexpected, because banks should be forced to retain interest in securitized mortgages due to the information asymmetry problems discussed in Section 3. There could be several reasons why many banks present zero amounts of retained interest. The schedule on securitization activities in the FR Y-9C report may not capture all possible forms of credit enhancements. For example, over-collateralization or the installation of a reserve account could be forms of credit enhancement that do not lead to a credit exposure reportable in the schedule of securitization activities. It is also possible that some banks obtained third-party guarantees for which fees are paid from current interest collections. ${ }^{30}$ Landsman et al. (2008) describe several possible forms of credit enhancements, including over-collateralization, third-party insurance or guarantees, retained interest and implicit recourse. They claim that typically the originator provides the bulk of the credit enhancement because third-party credit enhancement is likely to suffer from information asymmetry problems. Third parties will only be willing to offer such guarantees at a prohibitively high cost, reducing the incentive to use securitization as a means to issue debt. Based on this argument, it seems unlikely that the reason for the large number of observations with zero retained interest is due to third-party guarantees. Another explanation would be that banks sold their retained interest subsequent to securitization. Fender and Mitchell (2009a) argue that over time relatively active markets for first-loss pieces developed, allowing originators to sell their retained interest. Last but not least, the observation that some banks do not hold retained interest could be in line with the hypotheses developed in this paper. Therefore, the sensitivity analysis in this section will separately examine

30 For a discussion of the different forms of credit enhancements and their cost and benefits see Kothari (2006), pp. 291-230. 
the group of banks which hold positive amounts of retained interest.

Table 7 presents results for estimates of Model 1 using a subsample of banks and using different regression techniques, respectively. The first two columns report estimates for the subsample of banks with positive amounts of Retained Interest. Results for the random-effects model are reported in the column RI Banks only: RE and generally compare to the results for the full sample from Table 4. As predicted, the coefficients on Delinquent Securitized Mortgages and Trading Assets are positive and significantly different from zero at the 5 percent level. Consistent with Hypotheses 2 and 4, the coefficients on High Reputation and Non Performing Loans are negative as predicted and also significant at the 10 percent and 5 percent level, respectively. With regard to the control variables, all coefficients have the same sign as in Table 4 except for the coefficient on Total Assets, which is now slightly negative, but neither economically nor statistically significant. The $R^{2}$ in this specification is 12.5 percent suggesting a decent explanatory power.

The second column of Table 7 RI Banks only: FE presents estimates from a fixed-effects regression for the subsample of banks with positive amounts of Retained Interest. Results are similar to estimates for the full sample as reported in Table 4. Only the coefficient on Deposits has changed its sign, but is still not statistically significant. The model has an $R^{2}$ of 13 percent. This is somewhat higher than the $R^{2}$ for the full sample, reflecting the exclusion of the observations with zero retained interest.

The third column Tobit reports results from a tobit regression of Model 1. Tobit models are suitable for datasets with corner solution responses. In the dataset of this paper, the large fraction of banks with zero retained interest represents a corner solution. Therefore, I estimate a tobit model with a lower limit of zero to analyze the determinants of retained interest. The coefficient estimates have all the expected sign. My measure of credit risk, Delinquent Securitized Mortgages has a coefficient of 1.572 and is significant at the 1 percent level. As predicted, the coefficient on High Reputation is negative and significant at the 1 percent level. Moreover, Trading assets have a positive coefficient, which however is not significant at conventional levels. The coefficient on Non Performing Loans is negative as expected and statistically significant at the 10 percent level. The coefficients on the control variables also have the predicted signs. These results additionally support my hypotheses about the determinants of retained interest.

As an additional robustness check, the fourth column 2 Cluster presents estimates for an OLS regression of Model 1 with standard errors clustered by firm and quarter to correct for cross-sectional and time-series correlation of error terms. For most of 
the variables, the coefficients are not statistically significant in this specification. One exception is the coefficient on Delinquent Securitized Mortgages which is positive and statistically significant at the 1 percent level. In addition, the signs of all other variables including the controls are as predicted. For High Reputation and Non Performing Loans the estimated coefficients are close to significance at conventional levels (two-sided $p$-values of 10.3 percent and 12.3 percent, respectively). Therefore, the results from this sensitivity analysis provide at least some evidence consistent with the developed hypotheses about the determinants of retained interest.

Finally, the last column of Table 7 reports results from a regression of Model 1 using an alternative definition of the dummy for an established reputation for securitization transactions. This test serves as a robustness check of the definition of High Reputation. The dummy Mkt Share is one if the bank's share of the total issuance volume of non-agency mortgage-backed securities is at least 2 percent in any year of the sample period, otherwise the dummy is zero. Results generally compare to the estimates reported in Table 4. The coefficients on Delinquent Securitized Mortgages and Trading Assets are significantly positive at the 1 percent and 10 percent level, respectively. More importantly, the alternative dummy for bank reputation Mkt Share is negative as expected and significantly different from zero at the 1 percent level. In addition, Non Performing Loans have a negative coefficient which is significant at the 5 percent level. These results are again consistent with my hypotheses about the determinants of retained interest.

\section{[Insert Table 7 here]}

\subsection{Caveats}

My research findings are subject to a number of limitations. The presumably severest of them relates to the type of data used to test the hypotheses. Retained interest is the result of a securitization transaction that occurs at a certain point in time. At this point in time, the originating bank retains a portion of the securitized assets. Because securitizations and the accompanying creation of retained interest are discrete transactions, it would be more appropriate to use transaction level data to examine the determinants of retained interest. In contrast, the data used in this study are taken from quarterly balance sheets and thus are static. Based on this

static dataset, the results of this study provide evidence on the combined decision to retain interest from a securitization transaction and the decision to hold such retained interest in subsequent periods. A possible remedy would be to use transaction level data. There are databases which collect issuance of new ABS, but it would still 
be difficult to identify which portion of the issuance volume is retained interest. Such information would need to be hand collected from the security prospectus. Hand-collected data would be subject to substantial judgement when standardizing the different information from different prospectuses. It could also be subject to a selection bias because there might be private placements of ABS with no public prospectus available.

Besides, it is possible that there is an identification issue in the empirical design of the study. Conclusions based on the empirical analysis hold only if the used variables are valid proxies for the theoretical determinants of retained interest. In particular, the validity of my findings depends on the extent that e.g. the portion of delinquent amounts in securitized mortgages is a valid proxy for the credit risk of the securitized mortgages. Similarly, the portion of trading assets needs to be a valid proxy for a bank's sophistication. In order to mitigate potential identification issues, I used different proxies for the theoretical determinants in untabulated regressions. The results remained substantially unaffected. However, except for net charge-offs of securitized mortgages there is currently no other variable that could be used as a proxy for credit risk of the securitized mortgages. I consider this a minor problem, since past due amounts are a common proxy for credit risk of loans in other studies (see e.g. Purnanandam, 2011).

\section{Conclusions}

This paper analyzes bank- and loan-specific characteristics that determine the amount of retained interest held by US banks in mortgage securitizations. Securitization transactions usually take place under information asymmetry between securitizers and investors in asset-backed securities. Economic theory suggests that retaining an interest in securitization transactions should help to mitigate information asymmetry problems. Such retained interest represents a concentrated and often complex exposure to the risks of the transferred assets. Therefore, the level of retained interest should be positively associated with the credit risk of the securitized mortgages and with the level of sophistication of a bank. In addition, a high reputation for securitization transactions should also mitigate information asymmetry problems, while banks with already high risk exposures from other assets, in particular credit risk exposure from loans, should have less of an incentive to hold retained interest. The last two characteristics should therefore be negatively associated with the level of retained interest. 
Using a sample of US bank holding companies for the period 2001 to 2006, I provide evidence consistent with these hypotheses. In random-effects and fixed-effects regressions of retained interest, my measures of credit risk of the securitized mortgages and of a bank's sophistication are significantly positively associated with the level of retained interest. In contrast, bank reputation and credit risk exposure from on-balance-sheet loans are significantly negatively associated with the level of retained interest. These findings are robust to the analysis of different subsamples of banks and to the use of different regression techniques.

However, the findings also suggest that a large fraction of banks at least did not hold retained interest during the entire life of their mortgage-backed securities. Splitting sample banks into different groups according to their business models shows that banks with an originate-to-distribute business model held relatively small retained interest while having securitized assets with relatively high credit risk. This observation is consistent with the view that for this particular group of banks investors neglected the risk of the securitized mortgages.

Analyzing incentives for earnings management, I do not find evidence that banks smooth reported net income through overstating the value of retained interest from securitization transactions. This result is consistent with average small securitization income that generally does not offer much discretion to smooth net income.

My study extends prior research which has until now focused on the impact of securitization transactions on securitizers' equity or credit risk. Prior research has generally shown that securitized assets are risk relevant for the securitizing firm (Niu and Richardson, 2006; Landsman et al., 2008; Chen et al., 2008; Barth et al., 2012). There is evidence that the source of this risk relevance is retained interest in the securitized assets. Yet, there is little empirical research on the motives and the extent of risk retention in securitization transactions. My paper aims to contribute to these questions. The findings provide evidence that retained interest in securitization transactions serves as a mechanism to mitigate information asymmetry problems as well as a means to manage a bank's risk profile. These results are relevant for researchers who are studying the capital market consequences of securitization transactions. The results are also relevant for policy makers when making decisions about regulation of risk retention in securitization transactions. 


\section{References}

Affinito, M. and E. Tagliaferri (2010). Why do (or did?) banks securitize their loans? evidence from italy. Journal of Financial Stability 6(4), 189-202.

Ashcraft, A. B. and T. Schuermann (2008). Understanding the securitization of subprime mortgage credit. In G. M. Constantinides, F. Allen, A. W. Lo, and R. M. Stulz (Eds.), Foundations and Trends in Finance, Volume 2. Now Publishers.

Ball, R., R. M. Bushman, and F. P. Vasvari (2008). The debt-contracting value of accounting information and loan syndicate structure. Journal of Accounting Research 46(2), pp. 247-287.

Bannier, C. E. and D. N. Hänsel (2008). Determinants of european banks' engagment in loan securitization. Deutsche Bundesbank Discussion Paper.

Barth, M. and D. Taylor (2010). In defense of fair value: Weighing the evidence on earnings management and asset securitizations. Journal of Accounting and Economics 49(1-2), 26 - 33. Conference Issue on Current Issues in Accounting: Reassessing the Regulation of Capital Markets; University of Rochester, William E. Simon Graduate School of Business Administration.

Barth, M. E., G. Ormazabal, and D. J. Taylor (2012). Asset securitizations and credit risk. The Accounting Review 87(2), 423-448.

BCBS (2000). Principles for management of credit risk. Risk Management Group of the Basel Committee on Banking Supervision.

BCBS (2011). Report on asset securitisation incentives. The Joing Forum: Basel Committee on Banking Supervision, International Organization of Securities Commissions, International Association of Insurance Supervisors.

Beaver, W. H. and E. E. Engel (1996). Discretionary behavior with respect to allowances for loan losses and the behavior of security prices. Journal of Accounting and Economics 22, 177-206.

Board of Governors of the Federal Reserve System (2001). Instructions for preparation of consolidated financial statements for bank holding companies - reporting form FR Y9-C - for march 2001. 
Board of Governors of the Federal Reserve System (2002b). Instructions for preparation of consolidated financial statements for bank holding companies - reporting form FR Y9-C - for june 2002.

Board of Governors of the Federal Reserve System (2002a). Instructions for preparation of consolidated financial statements for bank holding companies - reporting form FR Y9-C - for march 2002.

Board of Governors of the Federal Reserve System (2010). Report to the congress on risk retention. http://federalreserve.gov/boarddocs/rptcongress/securitization/riskretention.pdf.

Board of Governors of the Federal Reserve System (2013). Regulatory reform: Implementing the dodd-frank act: The federal reserve board's role. http://www.federalreserve.gov/newsevents/reform.htm.

Boot, A. W. A. and A. V. Thakor (1993). Security design. The Journal of Finance 48(4), 1349-1378.

Bryan, S., S. B. Lilien, and B. Sarath (2010). Countering opportunism in structuring and valuing transactions: The case of securitizations. Journal of Accounting, Auditing \& Finance 25, 289-321.

Burgstahler, D. and I. Dichev (1997). Earnings management to avoid earnings decreases and losses. Journal of Accounting and Economics 24, 99-126.

Calomiris, C. W. and J. R. Mason (2004). Credit card securitization and regulatory arbitrage. Journal of Financial Services Research 26, 5-27.

Cantrell, B. W., J. M. McInnis, and C. G. Yust (2013). Predicting credit losses: Loan fair values versus historical costs. Working Paper.

Capital Requirement Directive II (2009). Directive 2009/111/ec of the european parliament and of the council of 16 september 2009 amending directives 2006/48/ec, 2006/49/ec and 2007/64/ec as regards banks affiliated to central institutions, certain own funds items, large exposures, supervisory arrangements, and crisis management. http://eurlex.europa.eu/LexUriServ/LexUriServ.do?uri=OJ:L:2009:302:0097:01:en:HTML.

Casu, B., A. Clare, A. Sarkisyan, and S. Thomas (2011). Does securitization reduce credit risk taking? empirical evidence from US bank holding companies. The European Journal of Finance 17(9-10), 767-788. 
Chen, W., C.-C. Liu, and S. G. Ryan (2008). Characteristics of securitizations that determine issuers' retention of the risks of the securitized assets. The Accounting Review 83(5), 1181-1215.

City Holding Company (2002). Annual report on form 10-K for the year ended december 31, 2001. http://www.sec.gov/Archives/edgar/data/726854/000091664102000415/000091664102-000415.txt.

Code of Federal Regulations (2012). Title 12 - Banks and Banking. http://www.gpo.gov/fdsys/browse/collectionCfr.action?selectedYearFrom=2012\&page.go $=$ Go.

Cumming, C. (1987). The economics of securitization. FRBNY Quarterly Review, $11-23$.

Dechow, P. M., L. A. Myers, and C. Shakespeare (2010). Fair value accounting and gains from asset securitizations: A convenient earnings management tool with compensation side-benefits. Journal of Accounting and Economics 49(1-2), 2 - 25. Conference Issue on Current Issues in Accounting: Reassessing the Regulation of Capital Markets; University of Rochester, William E. Simon Graduate School of Business Administration.

Dechow, P. M. and C. Shakespeare (2009). Do managers time securitization transactions to obtain accounting benefits? The Accounting Review 84(1), 99 - 132.

DeMarzo, P. and D. Duffie (1999). A liquidity based model of security design. Econometrica 67(1), 65-99.

Dodd-Frank Act (2010). Dodd-frank wall street reform and consumer protection act. H. R. 4173.

FASB (2000). SFAS 140: Accounting for transfers and servicing of financial assets and extinguishments of liabilities. Norfolk, CT. September 2000.

Federal Agencies (2011). Credit risk retention - proposed rule by the department of the treasury, the federal reserve system, the federal deposit insurance corporation, the us securities and exchange commission, the federal housing finance agency and the department of housing and urban development. Federal Register 76 (83), 24090-24186. http://www.gpo.gov/fdsys/pkg/FR-2011-04-29/pdf/2011-8364.pdf. 
Fender, I. and J. Mitchell (2009a, September). The future of securitisation: how to align incentives? BIS Quarterly Review 14, 27-43.

Fender, I. and J. Mitchell (2009b). Incentives and tranche retention in securitisation: A screening model. Working Paper National Bank of Belgium.

Franke, G., M. Herrmann, and T. Weber (2012). Loss allocation in securitization transactions. Journal of Financial and Quantitative Analysis 47(5), 1125 - 1153.

Franke, G. and J. P. Krahnen (2007). Default risk sharing between banks and markets: The contribution of collateralized debt obligations. In M. Carey and R. M. Stulz (Eds.), The Risks of Financial Institutions, Chapter 13, pp. 603-634. University of Chicago Press.

Franke, G. and J. P. Krahnen (2008). The future of securitization. Center For Financial Studies Working Paper.

Gorton, G. B. and G. G. Pennacchi (1995). Banks and loan sales marketing nonmarketable assets. Journal of Monetary Economics 35(3), 389 - 411.

Greenbaum, S. I. and A. V. Thakor (1987). Bank funding modes: Securitization versus deposits. Journal of Banking \& Finance 11(3), 379-401.

Harris, T., U. Khan, and D. Nissim (2013). The expected rate of credit losses on banks' loan portfolios. Working Paper.

Hattori, M. and K. Ohashi (2011). Detrimental effects of retention regulation: Incentives for loan screening in securitization under asymmetric information. Working Paper Bank of Japan/ Hitotsubashi University.

Herring, R. and T. Schuermann (2005). Capital regulation for position risk in banks, securities firms, and insurance companies. In H. S. Scott (Ed.), Capital Adequacy Beyond Basel: Banking, Securities, and Insurance, Chapter 1, pp. 15-86. Oxford University Press, Oxford et al.

Karaoglu, N. E. (2005). Regulatory Capital and Earnings Management in Banks: The Case of Loan Sales and Securitizations. SSRN eLibrary.

Keys, B. J., T. Mukherjee, A. Seru, and V. Vig (2010). Did securitization lead to lax screening? evidence from subprime loans. The Quarterly Journal of Economics 125(1), 307-362. 
Kiff, J. and M. Kisser (2010). Asset Securitization and Optimal Retention. Working Paper IMF.

Kiff, J. and M. Kisser (2012). A shot at regulating securitization. Working Paper Norwegian School of Economics.

Kothari, V. (2006). Securitization - The Financial Instrument of the Future. Wiley finance series. John Wiley \& Sons (Asia) Pte Ltd.

Landsman, W. R., K. V. Peasnell, and C. Shakespeare (2008). Are asset securitizations sales or loans? The Accounting Review 83(5), 1251-1272.

Liu, C.-C., S. G. Ryan, and H. Tan (2004). How banks' value-at-risk disclosures predict their total and priced risk: Effects of bank technical sophistication and learning over time. Review of Accounting Studies 9(2-3), 265-294.

Malekan, S. and G. Dionne (2012). Securitization and optimal retention under moral hazard. Working Paper HEC Montréal.

Martín-Oliver, A. and J. Saurina (2007). Why do banks securitize assets? Banco de Espana Working Paper.

Mazzuca, M. and M. Agostino (2009). Why do banks securitize? the case of italy. Banacaria - The Italian Banking Association Monthly (9), 18-38.

Niu, F. F. and G. D. Richardson (2006). Are securitizations in substance sales or secured borrowings? capital-market evidence. Contemporary Accounting Research 23(4), 1105-1133.

Panetta, F. and A. F. Pozzolo (2010). Why do banks securitize their assets? bank-level evidence from over one hundred countries. Working Paper, SSRN.

Pavel, C. and D. Phillis (1987). Why commercial banks sell loans: An empirical analysis. Economic Perspectives 11, 3-14.

Pennacchi, G. G. (1988). Loan sales and the cost of bank capital. The Journal of Finance 43(2), pp. 375-396.

Provident Financial Group, Inc. (2002). Annual report on form 10-K for the year ended december 31, 2001. http://www.sec.gov/Archives/edgar/data/316770/000031677002000008/y01q410kbody.htm. 
Purnanandam, A. (2011). Originate-to-distribute model and the suprime mortgage crisis. The Review of Financial Studies 24(6), 1881-1914.

Regions Financial Corporation (2002). Annual report on form 10-K for the year ended december 31, 2001. http://www.sec.gov/Archives/edgar/data/36032/000095014402002612/g74804e10k405.txt.

Republic Bancshares, Inc. (1999). Annual report on form 10-K for the year ended december 31, 1998. http://www.sec.gov/Archives/edgar/data/1005501/000095014499-003506.txt.

Schipper, K. and T. L. Yohn (2007). Standard setting issues and academic research related to the accounting for financial asset transfers. Accounting Horizons 21(1), $59-80$.

Senate Report 111-176 (2010). The restoring american financial stability act of 2010. http://www.gpo.gov/fdsys/pkg/CRPT-111srpt176/pdf/CRPT111srpt176.pdf. Calendar No. 349.

SIFMA (2012a). US bond markets issuance. http://www.sifma.org/research/statistics.aspx. Quarterly data to Q2 2012. Updated 07/12/12.

SIFMA (2012b). US mortgage-related issuance and outstanding. http://www.sifma.org/re-search/statistics.aspx. Data from 1996 to June 2012. Updated 07/05/12.

Sufi, A. (2007). Information asymmetry and financing arrangements: Evidence from syndicated loans. The Journal of Finance 62(2), 629-668.

United Bankshares, Inc. (2000). Annual report on form 10-K for the year ended december 31, 1999. http://www.sec.gov/Archives/edgar/data/729986/000095016900-000247.txt.

Uzun, H. and E. Webb (2007). Securitization and risk: empirical evidence on us banks. The Journal of Risk Finance 8, 11 - 23.

Wahlen, J. M. (1995). The nature of information in commercial bank loan loss disclosures. The Accounting Review 69(3), 455-478. 
Figure 1: Typical structure of a securitization transaction

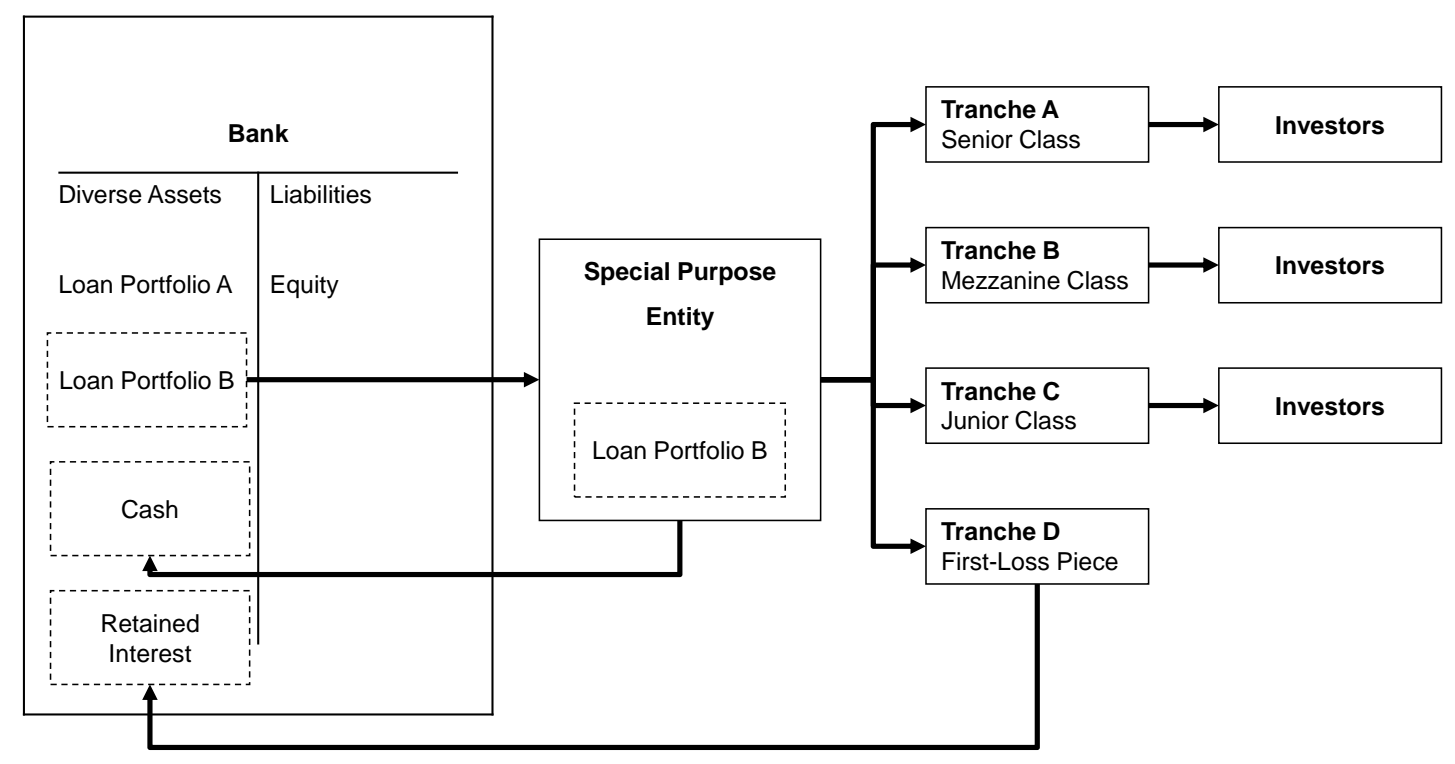


Table 1: Distribution of retained interest and bank- and loan-specific variables

\begin{tabular}{|c|c|c|c|c|c|c|c|c|}
\hline & mean & $\min$ & $\mathrm{p} 25$ & $\mathrm{p} 50$ & $\mathrm{p} 75$ & p95 & $\max$ & count \\
\hline Retained Interest & 0.044 & 0.000 & 0.000 & 0.000 & 0.023 & 0.244 & 0.991 & 1,355 \\
\hline Interest-only Strips & 0.010 & 0.000 & 0.000 & 0.000 & 0.000 & 0.047 & 0.574 & 1,355 \\
\hline Subord. ABS \& Other Interest & 0.032 & 0.000 & 0.000 & 0.000 & 0.002 & 0.178 & 0.991 & 1,350 \\
\hline thereof: Subord. ABS & 0.020 & 0.000 & 0.000 & 0.000 & 0.000 & 0.137 & 0.730 & 886 \\
\hline thereof: Standby Letters of Credit & 0.013 & 0.000 & 0.000 & 0.000 & 0.000 & 0.056 & 0.342 & 884 \\
\hline Liquidity Commitments & 0.000 & 0.000 & 0.000 & 0.000 & 0.000 & 0.000 & 0.065 & 1,335 \\
\hline & & $\cdot$ & & 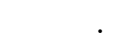 & & & & 0 \\
\hline Delinquent Securitized Mortgages & 0.027 & 0.000 & 0.000 & 0.001 & 0.041 & 0.120 & 0.298 & 1,355 \\
\hline High Reputation & 0.128 & 0.000 & 0.000 & 0.000 & 0.000 & 1.000 & 1.000 & 1,355 \\
\hline Trading Assets & 0.013 & 0.000 & 0.000 & 0.000 & 0.007 & 0.091 & 0.260 & 1,355 \\
\hline Non Performing Loans & 0.010 & 0.000 & 0.004 & 0.008 & 0.014 & 0.028 & 0.054 & 1,355 \\
\hline Total Assets & 15.333 & 10.607 & 13.100 & 15.431 & 17.259 & 19.728 & 21.014 & 1,355 \\
\hline Deposits & 0.688 & 0.077 & 0.611 & 0.710 & 0.796 & 0.878 & 0.906 & 1,355 \\
\hline Outstanding Securitized Mortgages & 0.138 & 0.000 & 0.005 & 0.031 & 0.127 & 0.559 & 2.593 & 1,355 \\
\hline
\end{tabular}

This table presents descriptive statistics for total retained interest, the components of retained interest and the variables used in the regression analysis of Retained Interest for the period 2001-2006. Retained Interest is the total of all types of recourse or other credit enhancements provided in mortgage securitizations. Interest-only Strips are credit-enhancing interest-only strips. Subord. ABS 85 Other Interest is the total of subordinated securities, standby letters of credit and other enhancements. Subord. ABS are subordinated securities and other residual interests. Standby Letters of Credit are standby letters of credit and other enhancements. Liquidity Commitments is the unused portion of a bank's commitments to provide liquidity to securitization structures. Total retained interest and the components of retained interest are scaled by the bank's outstanding principal balance of mortgages securitized for which servicing or recourse or other credit enhancements have been retained.

Delinquent Securitized Mortgages is the total of outstanding securitzed mortgages past due 30-89 days and outstanding securitized mortgages 90 or more days past due scaled by the bank's outstanding principal balance of mortgages securitized. High Reputation is one if a bank or one of its subsidiaries has been among the top 25 issuers of non-agency mortgage-backed securities in the research period and zero otherwise. Trading Assets is the amount of trading assets scaled by total assets. Non Performing Loans is the total of loans and leases 90 or more days past due and loans and leases on nonaccrual status scaled by the total of all loans and leases. Total Assets is the natural logarithm of total assets in thousand US-\$. Deposits is the total of domestic and foreign deposits scaled by total assets. Outstanding Securitized Mortgages is the bank's outstanding principal balance of mortgages securitized scaled by total assets. 
Table 2: Distribution of bank- and loan-specific variables by bank type

\begin{tabular}{|c|c|c|c|c|c|c|c|c|c|c|c|c|}
\hline & \multicolumn{3}{|c|}{ OTD Banks } & \multicolumn{3}{|c|}{ Universal Banks } & \multicolumn{3}{|c|}{ Div. Comm. Banks } & \multicolumn{3}{|c|}{ Trad. Comm. Banks } \\
\hline & $\mathrm{N}$ & Mean & Median & $\mathrm{N}$ & Mean & Median & $\mathrm{N}$ & Mean & Median & $\mathrm{N}$ & Mean & Median \\
\hline Total Assets in bn USD & 51 & 81.90 & 19.81 & 293 & 154.64 & 28.84 & 243 & 104.38 & 2.18 & 723 & 11.93 & 0.79 \\
\hline Mortgages & 51 & 0.41 & 0.40 & 293 & 0.31 & 0.32 & 243 & 0.39 & 0.40 & 723 & 0.51 & 0.51 \\
\hline Consumer Loans & 51 & 0.03 & 0.01 & 293 & 0.07 & 0.08 & 243 & 0.06 & 0.04 & 723 & 0.05 & 0.04 \\
\hline Comm. \& Other Loans & 51 & 0.06 & 0.03 & 293 & 0.16 & 0.15 & 243 & 0.13 & 0.13 & 723 & 0.14 & 0.14 \\
\hline Loans Held for sale & 48 & 0.17 & 0.17 & 293 & 0.01 & 0.00 & 240 & 0.03 & 0.01 & 723 & 0.02 & 0.00 \\
\hline Securities & 51 & 0.23 & 0.14 & 293 & 0.28 & 0.27 & 243 & 0.25 & 0.25 & 723 & 0.19 & 0.19 \\
\hline Trading Assets & $\begin{array}{r}51 \\
0\end{array}$ & 0.07 & 0.07 & $\begin{array}{r}293 \\
0\end{array}$ & 0.03 & 0.00 & $\begin{array}{r}243 \\
0\end{array}$ & 0.02 & 0.00 & $\begin{array}{r}723 \\
0\end{array}$ & 0.00 & 0.00 \\
\hline Deposits & 51 & 0.36 & 0.27 & 293 & 0.58 & 0.59 & 243 & 0.67 & 0.68 & 723 & 0.75 & 0.76 \\
\hline Repos \& FedFunds Purchased & 45 & 0.23 & 0.24 & 284 & 0.11 & 0.09 & 239 & 0.06 & 0.03 & 722 & 0.04 & 0.03 \\
\hline Other Borrowings & 41 & 0.16 & 0.17 & 293 & 0.12 & 0.12 & 243 & 0.11 & 0.11 & 723 & 0.09 & 0.08 \\
\hline Other Liabilities & $\begin{array}{r}51 \\
0\end{array}$ & 0.28 & 0.23 & $\begin{array}{r}280 \\
0\end{array}$ & 0.17 & 0.18 & $\begin{array}{r}243 \\
0\end{array}$ & 0.16 & 0.17 & $\begin{array}{r}723 \\
0\end{array}$ & 0.11 & 0.09 \\
\hline Tier 1 Capital Ratio & 51 & 0.13 & 0.12 & 291 & 0.12 & 0.11 & 243 & 0.11 & 0.11 & 711 & 0.11 & 0.11 \\
\hline Non Performing Loans & 51 & 0.02 & 0.03 & 293 & 0.01 & 0.01 & 243 & 0.01 & 0.01 & 723 & 0.01 & 0.01 \\
\hline Net Interest Income / BVE & $\begin{array}{r}50 \\
0\end{array}$ & 0.08 & 0.06 & $\begin{array}{r}293 \\
0\end{array}$ & 0.09 & 0.09 & $\begin{array}{r}242 \\
0\end{array}$ & 0.09 & 0.09 & $\begin{array}{r}718 \\
0\end{array}$ & 0.11 & 0.10 \\
\hline Loan Loss Provision & 50 & 0.08 & 0.07 & 292 & 0.10 & 0.09 & 239 & 0.08 & 0.07 & 719 & 0.06 & 0.05 \\
\hline Total Noninterest Income & 50 & 1.53 & 1.69 & 291 & 0.71 & 0.54 & 231 & 0.76 & 0.43 & 723 & 0.37 & 0.31 \\
\hline Trading Income & 41 & -0.12 & -0.03 & 292 & 0.03 & 0.00 & 240 & 0.05 & 0.00 & 723 & 0.00 & 0.00 \\
\hline Inv. Banking \& Brokerage Income & 50 & 0.03 & 0.01 & 287 & 0.19 & 0.02 & 233 & 0.17 & 0.01 & 723 & 0.02 & 0.01 \\
\hline Servicing Income & 44 & -0.00 & 0.03 & 292 & 0.02 & 0.01 & 241 & 0.04 & 0.04 & 718 & 0.01 & 0.00 \\
\hline Securitization Income & 43 & 0.07 & 0.02 & 293 & 0.02 & 0.00 & 241 & 0.02 & 0.00 & 723 & 0.00 & 0.00 \\
\hline Gain/Loss from Sale of Loans & $\begin{array}{r}42 \\
0\end{array}$ & 0.39 & 0.21 & $\begin{array}{r}293 \\
0\end{array}$ & 0.02 & 0.01 & $\begin{array}{r}242 \\
0\end{array}$ & 0.07 & 0.02 & $\begin{array}{r}723 \\
0\end{array}$ & 0.05 & 0.01 \\
\hline High Reputation & 51 & 0.53 & 1.00 & 293 & 0.21 & 0.00 & 243 & 0.25 & 0.00 & 723 & 0.03 & 0.00 \\
\hline Securitization Ratio & 51 & 3.31 & 3.07 & 293 & 0.11 & 0.05 & 243 & 0.78 & 0.76 & 723 & 0.07 & 0.03 \\
\hline Mortgages Serviced for Others & 48 & 2.19 & 1.58 & 293 & 0.09 & 0.04 & 242 & 0.61 & 0.33 & 721 & 0.25 & 0.04 \\
\hline Outstanding Securitized Mortgages & 51 & 1.37 & 1.09 & 293 & 0.03 & 0.01 & 243 & 0.30 & 0.31 & 723 & 0.04 & 0.02 \\
\hline Delinquent Securitized Mortgages & 51 & 0.06 & 0.05 & 293 & 0.04 & 0.01 & 243 & 0.02 & 0.01 & 723 & 0.02 & 0.00 \\
\hline Retained Interest & 51 & 0.03 & 0.00 & 293 & 0.09 & 0.02 & 243 & 0.02 & 0.00 & 723 & 0.04 & 0.00 \\
\hline
\end{tabular}

This table presents descriptive statistics for bank- and loan-specific variables by type of bank for the period 2001-2006. OTD Banks are banks with an orginate-to-distribute (OTD) business model. Div. Comm. Banks are diversified commercial banks. Trad. Comm. Banks are traditional commercial banks. Mortgages are loans secured by real estate. Consumer Loans are credit card loans and other consumer loans. Comm. \& Other Loans are commercial and industrial and all other loans and leases. Loans Held for Sale are loans and leases held for sale. Securities is the total of held-to-maturity securities and available-for-sale securities. Trading Assets are trading assets.

Deposits is the total of domestic and foreign deposits. Repos 83 FedFunds Purchased are securities sold under repurchase agreements and federal funds purchased. Other Borrowings is other borrowed money and includes, but is not limited to commercial papers, promissory notes, and borrowings from Federal Reserve Banks. Other Liabilities are other liabilites and include, but are not limited to accounts payable and recourse liabilities.

Tier 1 Capital Ratio is the tier 1 risk-based capital ratio. Non Performing Loans is the total of loans and leases 90 or more days past due and loans and leases on nonaccrual 
status scaled by the total of all loans and leases. Net Interest Income / $B V E$ is the difference between total interest income and total interest expense scaled by the book value of shareholders' equity.

Loan Loss Provision are provision for loan and lease losses. Total Noninterest Income is the total noninterest income. Trading Income is net trading income. Inv. Banking $E$ Brokerage Income is net income from investment banking, advisory, brokerage, and underwriting services. Servicing Income is net income from the servicing of loans held by others. Securitization Income is net income from securitization transactions. Gain/Loss from Sale of Loans are net gains (losses) on sales of loans and leases.

High Reputation is one if a bank or one of its subsidiaries has been among the top 25 issuers of non-agency mortgage-backed securities in the research period and zero otherwise. Securitization Ratio is the bank's outstanding principal balance of mortgages securitized scaled by on-balance-sheet mortgages. Mortgages Serviced for Others are residential mortgages serviced for others with and without recourse provided scaled by total assets. Outstanding Securitized Mortgages is the bank's outstanding principal balance of mortgages securitized scaled by total assets. Delinquent Securitized Mortgages is the total of outstanding securitzed mortgages past due 30-89 days and outstanding securitized mortgages 90 or more days past due scaled by the bank's outstanding principal balance of mortgages securitized. Retained Interest is the total of all types of recourse or other credit enhancements provided in mortgage securitizations scaled by the bank's outstanding principal balance of mortgages securitized.

On-balance-sheet assets and liabilities are scaled by total assets, except for Non Performing Loans and Retained Interest. Income and expense items are scaled by net interest income, except for Net Interest Income / BVE. 
Table 3: Correlation Matrix

\begin{tabular}{|c|c|c|c|c|c|c|c|c|}
\hline & $\begin{array}{l}\text { Retained } \\
\text { Interest }\end{array}$ & $\begin{array}{l}\text { Delinquent } \\
\text { Secu- } \\
\text { ritized } \\
\text { Mortgages }\end{array}$ & $\begin{array}{l}\text { High Rep- } \\
\text { utation }\end{array}$ & $\begin{array}{l}\text { Trading } \\
\text { Assets }\end{array}$ & $\begin{array}{l}\text { Non Per- } \\
\text { forming } \\
\text { Loans }\end{array}$ & $\begin{array}{l}\text { Total As- } \\
\text { sets }\end{array}$ & Deposits & $\begin{array}{l}\text { Outstanding } \\
\text { Secu- } \\
\text { ritized } \\
\text { Mortgages }\end{array}$ \\
\hline Retained Interest & 1.000 & & & & & & & \\
\hline Delinquent Securitized Mortgages & $\begin{array}{l}0.362^{* * *} \\
0.000\end{array}$ & 1.000 & & & & & & \\
\hline High Reputation & $\begin{array}{l}0.059^{* *} \\
0.031\end{array}$ & $\begin{array}{l}0.333^{* * *} \\
0.000\end{array}$ & 1.000 & & & & & \\
\hline Trading Assets & $\begin{array}{l}0.123^{\text {*** }} \\
0.000\end{array}$ & $\begin{array}{l}0.217^{* * *} \\
0.000\end{array}$ & $\begin{array}{l}0.636^{* * *} \\
0.000\end{array}$ & 1.000 & & & & \\
\hline Non Performing Loans & $\begin{array}{l}0.004 \\
0.889\end{array}$ & $\begin{array}{l}0.255^{* * *} \\
0.000\end{array}$ & $\begin{array}{l}0.075^{* * *} \\
0.006\end{array}$ & $\begin{array}{l}0.231^{* * *} \\
0.000\end{array}$ & 1.000 & & & \\
\hline Total Assets & $\begin{array}{l}0.251^{* * *} \\
0.000\end{array}$ & $\begin{array}{l}0.484^{* * *} \\
0.000\end{array}$ & $\begin{array}{l}0.587^{* * *} \\
0.000\end{array}$ & $\begin{array}{l}0.543^{* * *} \\
0.000\end{array}$ & $\begin{array}{l}0.094^{* * *} \\
0.001\end{array}$ & 1.000 & & \\
\hline Deposits & $\begin{array}{l}-0.179^{* * *} \\
0.000\end{array}$ & $\begin{array}{l}-0.336^{* * *} \\
0.000\end{array}$ & $\begin{array}{l}-0.357^{* * *} \\
0.000\end{array}$ & $\begin{array}{l}-0.525^{* * *} \\
0.000\end{array}$ & $\begin{array}{l}-0.270^{* * *} \\
0.000\end{array}$ & $\begin{array}{l}-0.631^{* * *} \\
0.000\end{array}$ & 1.000 & \\
\hline Outstanding Securitized Mortgages & $\begin{array}{l}-0.072^{* * *} \\
0.008\end{array}$ & $\begin{array}{l}0.076^{* * *} \\
0.005\end{array}$ & $\begin{array}{l}0.323^{* * *} \\
0.000\end{array}$ & $\begin{array}{l}0.278^{* * *} \\
0.000\end{array}$ & $\begin{array}{l}0.223^{* * *} \\
0.000\end{array}$ & $\begin{array}{l}0.134^{* * *} \\
0.000\end{array}$ & $\begin{array}{l}-0.344^{* * *} \\
0.000\end{array}$ & 1.000 \\
\hline Observations & 1,355 & & & & & & & \\
\hline
\end{tabular}

This table presents Pearson correlations coefficients, $p$-values and signficance levels for the variables used in the regression analysis of Retained Interest. ${ }^{*}$ $p<0.1,{ }^{* *} p<0.05,{ }^{* * *} p<0.01$. Retained Interest is the total of all types of recourse or other credit enhancements provided in mortgage securitizations scaled by the bank's outstanding principal balance of mortgages securitized. Delinquent Securitized Mortgages is the total of outstanding securitzed mortgages past due 30-89 days and outstanding securitized mortgages 90 or more days past due scaled by the bank's outstanding principal balance of mortgages securitized. High Reputation is one if a bank or one of its subsidiaries has been among the top 25 issuers of non-agency mortgage-backed securities in the research period and zero otherwise. Trading Assets is the amount of trading assets scaled by total assets. Non Performing Loans is the total of loans and leases 90 or more days past due and loans and leases on nonaccrual status scaled by the total of all loans and leases. Total Assets is the natural logarithm of total assets in thousand US-\$. Deposits is the total of domestic and foreign deposits scaled by total assets. Outstanding Securitized Mortgages is the bank's outstanding principal balance of mortgages securitized scaled by total assets. 
Table 4: Regression of retained interest on bank- and loan-specific variables

\begin{tabular}{|c|c|c|c|c|c|c|}
\hline & (1) & $(2)$ & $(3)$ & (4) & $(5)$ & $(6)$ \\
\hline & $\mathrm{FE}$ & $\mathrm{RE}$ & $\mathrm{RE}$ & $\mathrm{RE}$ & $\mathrm{RE}$ & FE \\
\hline \multirow[t]{2}{*}{ Delinquent Securitized Mortgages } & $0.632^{*}$ & $0.717^{* * *}$ & $0.734^{* * *}$ & $0.788^{* * *}$ & $0.789^{* * *}$ & $0.678^{* *}$ \\
\hline & $(0.335)$ & $(0.244)$ & $(0.244)$ & $(0.258)$ & $(0.265)$ & $(0.338)$ \\
\hline \multirow[t]{2}{*}{ High Reputation } & & -0.038 & $-0.058^{* *}$ & $-0.060^{* *}$ & $-0.067^{* *}$ & \\
\hline & & $(0.036)$ & $(0.030)$ & $(0.029)$ & $(0.031)$ & \\
\hline \multirow[t]{2}{*}{ Trading Assets } & & & 0.347 & 0.387 & 0.413 & $0.844^{* * *}$ \\
\hline & & & $(0.249)$ & $(0.252)$ & $(0.259)$ & $(0.305)$ \\
\hline \multirow[t]{2}{*}{ Non Performing Loans } & & & & $-1.381^{* *}$ & $-1.312^{* *}$ & $-1.545^{* *}$ \\
\hline & & & & $(0.622)$ & $(0.651)$ & $(0.721)$ \\
\hline \multirow[t]{2}{*}{ Total Assets } & 0.062 & $0.005^{*}$ & 0.005 & 0.004 & 0.004 & 0.080 \\
\hline & $(0.061)$ & $(0.003)$ & $(0.003)$ & $(0.003)$ & $(0.003)$ & $(0.060)$ \\
\hline \multirow[t]{2}{*}{ Deposits } & -0.075 & -0.033 & -0.015 & -0.027 & -0.025 & -0.031 \\
\hline & $(0.122)$ & $(0.051)$ & $(0.059)$ & $(0.056)$ & $(0.065)$ & $(0.127)$ \\
\hline \multirow[t]{2}{*}{ Outstanding Securitized Mortgages } & -0.014 & $-0.024^{*}$ & -0.024 & $-0.022^{*}$ & 0.010 & -0.015 \\
\hline & $(0.019)$ & $(0.014)$ & $(0.015)$ & $(0.013)$ & $(0.023)$ & $(0.020)$ \\
\hline \multirow[t]{2}{*}{ OTD Bank } & & & & & -0.055 & \\
\hline & & & & & $(0.053)$ & \\
\hline \multirow[t]{2}{*}{ Universal Bank } & & & & & 0.015 & \\
\hline & & & & & $(0.019)$ & \\
\hline \multirow[t]{2}{*}{ Div. Comm. Bank } & & & & & -0.009 & \\
\hline & & & & & $(0.012)$ & \\
\hline \multirow[t]{2}{*}{ Constant } & -0.864 & -0.040 & -0.046 & -0.017 & -0.021 & -1.160 \\
\hline & $(0.942)$ & $(0.066)$ & $(0.069)$ & $(0.065)$ & $(0.070)$ & $(0.934)$ \\
\hline R-Square Within & 0.050 & 0.042 & 0.046 & 0.054 & 0.060 & 0.067 \\
\hline R-Square Overall & 0.088 & 0.166 & 0.170 & 0.180 & 0.187 & 0.082 \\
\hline $\mathrm{F}$ & 2.896 & & & & & 3.146 \\
\hline Chi-Square & & 121.838 & 128.361 & 100.696 & 103.347 & \\
\hline Prob. $>$ F/ Chi-Square & 0.000 & 0.000 & 0.000 & 0.000 & 0.000 & 0.000 \\
\hline Observations & 1,355 & 1,355 & 1,355 & 1,355 & 1,310 & 1,355 \\
\hline
\end{tabular}

This table presents estimates from fixed-effects (FE) and random-effects (RE) regressions of retained interest on bank- and loan-specific variables for the period 2001-2006. Heteroscedasticity-robust standard errors clustered at the firm level are reported in parentheses. Significance levels are $* 0.1$, $* * 0.05$, *** 0.01. Quarter-fixed effects are included. Retained Interest is the total of all types of recourse or other credit enhancements provided in mortgage securitizations scaled by the bank's outstanding principal balance of mortgages securitized. Delinquent Securitized Mortgages is the total of outstanding 
securitzed mortgages past due 30-89 days and outstanding securitized mortgages 90 or more days past due scaled by the bank's outstanding principal balance of mortgages securitized. High Reputation is one if a bank or one of its subsidiaries has been among the top 25 issuers of non-agency mortgage-backed securities in the research period and zero otherwise. Trading Assets is the amount of trading assets scaled by total assets. Non Performing Loans is the total of loans and leases 90 or more days past due and loans and leases on nonaccrual status scaled by the total of all loans and leases. Total Assets is the natural logarithm of total assets in thousand US-\$. Deposits is the total of domestic and foreign deposits scaled by total assets. Outstanding Securitized Mortgages is the bank's outstanding principal balance of mortgages securitized scaled by total assets. OTD Bank, Universal Bank and Div. Comm. Bank are dummy variables for the different types of banks as defined in Subsection 5.1. OTD Banks are banks with an orginate-to-distribute (OTD) business model. Div. Comm. Banks are diversified commercial banks. 


\section{Table 5: Distribution of earnings management indicators}

\begin{tabular}{lcc}
\hline \hline & mean & count \\
\hline D.Loss before SecInc & 0.040 & 1,355 \\
D.Loss Avoided & 0.012 & 1,355 \\
D.Quarterly Decrease before SecInc & 0.387 & 1,355 \\
D.Quarterly Decrease Avoided & 0.019 & 1,355 \\
D.Annual Decrease before SecInc & 0.258 & 1,355 \\
D.Annual Decrease Avoided & 0.013 & 1,355 \\
\hline \hline
\end{tabular}

This table presents descriptive statistics for indicators of earnings management incentives during the period 2001-2006. D.Loss before SecInc is one if net income before securitization income is negative and zero otherwise. D.Loss Avoided is one if net income before securitization income is negative and net income after securitization income is positive and zero otherwise. D.Quarterly Decrease before SecInc is one if net income before securitization income has decreased from the prior to the current quarter and zero otherwise. D. Quarterly Decrease Avoided is one if net income before securitization income has decreased from the prior to the current quarter and net income after securitization income has increased or remained equal from the prior to the current quarter and zero otherwise. D.Annual Decrease before SecInc is one if net income before securitization income has decreased from the prior year's quarter to the current year's quarter and zero otherwise. D.Annual Decrease Avoided is one if net income before securitization income has decreased from the prior year's quarter to the current year's quarter and net income after securitization income has increased or remained equal from the prior year's quarter to the current year's quarter and zero otherwise. 
Table 6: Regression of retained interest on bank- and loan-specific variables and earnings management indicators

\begin{tabular}{|c|c|c|c|c|c|c|}
\hline & (1) & $(2)$ & $(3)$ & $(4)$ & $(5)$ & $(6)$ \\
\hline \multirow[t]{2}{*}{ Delinquent Securitized Mortgages } & $0.787^{* * *}$ & $0.787^{* * *}$ & $0.786^{* * *}$ & $0.788^{* * *}$ & $0.788^{* * *}$ & $0.788^{* * *}$ \\
\hline & $(0.259)$ & $(0.259)$ & $(0.258)$ & $(0.257)$ & $(0.258)$ & $(0.259)$ \\
\hline \multirow[t]{2}{*}{ High Reputation } & $-0.060^{* *}$ & $-0.060^{* *}$ & $-0.059^{* *}$ & $-0.060^{* *}$ & $-0.059^{* *}$ & $-0.059^{* *}$ \\
\hline & $(0.029)$ & $(0.029)$ & $(0.029)$ & $(0.029)$ & $(0.029)$ & $(0.029)$ \\
\hline \multirow[t]{2}{*}{ Trading Assets } & 0.387 & 0.396 & 0.387 & 0.376 & 0.386 & 0.388 \\
\hline & $(0.252)$ & $(0.256)$ & $(0.251)$ & $(0.244)$ & $(0.251)$ & $(0.252)$ \\
\hline \multirow[t]{2}{*}{ Non Performing Loans } & $-1.359^{* *}$ & $-1.388^{* *}$ & $-1.370^{* *}$ & $-1.387^{* *}$ & $-1.363^{* *}$ & $-1.378^{* *}$ \\
\hline & $(0.616)$ & $(0.623)$ & $(0.614)$ & $(0.630)$ & $(0.604)$ & $(0.620)$ \\
\hline \multirow[t]{2}{*}{ Total Assets } & 0.004 & 0.004 & 0.004 & 0.004 & 0.004 & 0.004 \\
\hline & $(0.003)$ & $(0.003)$ & $(0.003)$ & $(0.003)$ & $(0.003)$ & $(0.003)$ \\
\hline \multirow[t]{2}{*}{ Deposits } & -0.029 & -0.031 & -0.027 & -0.025 & -0.027 & -0.027 \\
\hline & $(0.056)$ & $(0.057)$ & $(0.057)$ & $(0.058)$ & $(0.056)$ & $(0.056)$ \\
\hline \multirow[t]{2}{*}{ Outstanding Securitized Mortgages } & $-0.022^{*}$ & $-0.022^{*}$ & $-0.022^{*}$ & $-0.023^{*}$ & $-0.022^{*}$ & $-0.022^{*}$ \\
\hline & $(0.013)$ & $(0.013)$ & $(0.013)$ & $(0.013)$ & $(0.013)$ & $(0.013)$ \\
\hline D.Loss before SecInc & $\begin{array}{c}-0.008 \\
(0.014)\end{array}$ & & & & & \\
\hline D.Loss Avoided & & $\begin{array}{r}-0.017 \\
(0.021)\end{array}$ & & & & \\
\hline D.Quarterly Decrease before SecInc & & & $\begin{array}{c}-0.003 \\
(0.004)\end{array}$ & & & \\
\hline D.Quarterly Decrease Avoided & & & & $\begin{array}{c}0.016 \\
(0.029)\end{array}$ & & \\
\hline D.Annual Decrease before SecInc & & & & & $\begin{array}{r}-0.002 \\
(0.006)\end{array}$ & \\
\hline D.Annual Decrease Avoided & & & & & & $\begin{array}{r}-0.006 \\
(0.009)\end{array}$ \\
\hline \multirow[t]{2}{*}{ Constant } & -0.015 & -0.013 & -0.016 & -0.019 & -0.016 & -0.017 \\
\hline & $(0.064)$ & $(0.064)$ & $(0.065)$ & $(0.066)$ & $(0.065)$ & $(0.065)$ \\
\hline R-Square & 0.180 & 0.181 & 0.180 & 0.182 & 0.180 & 0.180 \\
\hline Chi-Square & 108.880 & 110.738 & 102.308 & 109.689 & 112.210 & 102.593 \\
\hline Observations & 1,355 & 1,355 & 1,355 & 1,355 & 1,355 & 1,355 \\
\hline
\end{tabular}

This table presents estimates from a random-effects regression of retained interest on bank- and loan-specific variables and indicators of earnings management incentives for the period 2001-2006. Heteroscedasticity-robust standard errors clustered at the firm level are reported in parentheses. Significance levels are * 0.1 , ** 0.05 , *** 0.01 . Quarter-fixed effects are included. Retained Interest is the total of all types of recourse or other credit enhancements provided in mortgage securitizations scaled by the bank's outstanding principal balance of mortgages securitized. Delinquent Securitized Mortgages is the total of outstanding securitzed mortgages past due 30-89 days and outstanding securitized mortgages 90 or more days past due scaled by the bank's outstanding principal balance of mortgages securitized. High Reputation is one if a bank or one of its subsidiaries has been among the top 25 issuers of non-agency mortgage-backed securities in the research period and zero otherwise. Trading Assets is the amount of trading assets scaled by total assets. Non Performing Loans is the total of loans and leases 90 or more days past due and loans and leases on nonaccrual status scaled by the total of all loans and leases. Total Assets is the natural logarithm of total assets in thousand US-\$. Deposits is the total of domestic and foreign deposits scaled by total assets. Outstanding Securitized Mortgages is the bank's outstanding principal balance of mortgages securitized scaled by total assets. Earnings management indicators are as defined in Table 5 . 
Table 7: Sensitivity analysis

\begin{tabular}{|c|c|c|c|c|c|}
\hline & RI Banks only: RE & RI Banks only: FE & Tobit & 2 Cluster & Mkt Share Dummy \\
\hline \multirow[t]{2}{*}{ Delinquent Securitized Mortgages } & $1.035^{* *}$ & $0.907^{*}$ & $1.572^{* * *}$ & $0.903^{* * *}$ & $0.857^{* * *}$ \\
\hline & $(0.433)$ & $(0.530)$ & $(0.505)$ & $(0.296)$ & $(0.270)$ \\
\hline \multirow[t]{2}{*}{ High Reputation } & $-0.068^{*}$ & & $-0.213^{* * *}$ & -0.065 & \\
\hline & $(0.036)$ & & $(0.076)$ & $(0.040)$ & \\
\hline \multirow[t]{2}{*}{ Mkt Share } & & & & & $-0.133^{* * *}$ \\
\hline & & & & & $(0.042)$ \\
\hline \multirow[t]{2}{*}{ Trading Assets } & $0.699^{* *}$ & $1.138^{* *}$ & 1.024 & 0.431 & $0.550^{*}$ \\
\hline & $(0.325)$ & $(0.453)$ & $(0.662)$ & $(0.376)$ & $(0.309)$ \\
\hline \multirow[t]{2}{*}{ Non Performing Loans } & $-3.845^{* *}$ & $-3.577^{* *}$ & $-4.324^{*}$ & -1.370 & $-1.275^{* *}$ \\
\hline & $(1.718)$ & $(1.777)$ & $(2.598)$ & $(0.887)$ & $(0.600)$ \\
\hline \multirow[t]{2}{*}{ Total Assets } & -0.008 & 0.062 & $0.036^{* * *}$ & 0.005 & 0.005 \\
\hline & $(0.010)$ & $(0.092)$ & $(0.010)$ & $(0.004)$ & $(0.003)$ \\
\hline \multirow[t]{2}{*}{ Deposits } & -0.012 & 0.009 & -0.191 & -0.034 & -0.029 \\
\hline & $(0.117)$ & $(0.263)$ & $(0.129)$ & $(0.052)$ & $(0.055)$ \\
\hline \multirow[t]{2}{*}{ Outstanding Securitized Mortgages } & -0.067 & -0.079 & -0.018 & -0.029 & $-0.022^{*}$ \\
\hline & $(0.042)$ & $(0.063)$ & $(0.041)$ & $(0.024)$ & $(0.012)$ \\
\hline \multirow[t]{2}{*}{ Constant } & 0.241 & -0.943 & $-0.497^{* *}$ & -0.014 & -0.030 \\
\hline & $(0.196)$ & $(1.647)$ & $(0.206)$ & $(0.075)$ & $(0.074)$ \\
\hline R-Square & 0.125 & 0.130 & 0.700 & 0.177 & 0.249 \\
\hline F/ Chi-Square & 465.323 & 51.106 & 1.762 & 34.722 & 115.085 \\
\hline Prob. $>$ F/ Chi-Square & 0.000 & 0.000 & 0.008 & 0.000 & 0.000 \\
\hline Observations & 550 & 550 & 1,355 & 1,355 & 1,355 \\
\hline
\end{tabular}

This table presents estimates from different regression techniques for regressions of Retained Interest on bank- and loan-specific variables for the period 2001-2006. "RI Banks only: FE" is a fixed-effects regression including only banks with Retained Interest. "RI Banks only: RE" is a random-effects regression including only banks with Retained Interest. "2 Cluster" is a OLS regression with standard errors clustered by firm and quarter. "Tobit" is a tobit regression for data censored at zero as the lower limit. Heteroscedasticity-robust standard errors are reported in parentheses. Standard errors are clustered at the firm level in all regressions except for "2 Cluster". Significance levels are * $0.1, * * 0.05, * * * 0.01$. Quarter-fixed effects are included. Retained Interest is the total of all types of recourse or other credit enhancements provided in mortgage securitizations scaled by the bank's outstanding principal balance of mortgages securitized. Delinquent Securitized Mortgages is the total of outstanding securitzed mortgages past due 30-89 days and outstanding securitized mortgages 90 or more days past due scaled by the bank's outstanding principal balance of mortgages securitized. High Reputation is one if a bank or one of its subsidiaries has been among the top 25 issuers of non-agency mortgage-backed securities in the research period and zero otherwise. Mkt Share is one if the bank's share of the total issuance volume of non-agency mortgage-backed securities is at least 2 percent in the research period and zero otherwise. Trading Assets is the amount of trading assets scaled by total assets. Non Performing Loans is the total of loans and leases 90 or more days past due and loans and leases on nonaccrual status scaled by the total of all loans and leases. Total Assets is the natural logarithm of total assets in thousand US-\$. Deposits is the total of domestic and foreign deposits scaled by total assets. Outstanding Securitized Mortgages is the bank's outstanding principal balance of mortgages securitized scaled by total assets. 